\title{
Do analysts' cash flow forecasts improve their target price accuracy?
}

DOI:

10.1111/1911-3846.12369

\section{Document Version}

Accepted author manuscript

Link to publication record in Manchester Research Explorer

\section{Citation for published version (APA):}

Strong, N., \& Hashim, N. (2017). Do analysts' cash flow forecasts improve their target price accuracy?

Contemporary Accounting Research, 35(4), 1816-1842. https://doi.org/10.1111/1911-3846.12369

\section{Published in:}

Contemporary Accounting Research

\section{Citing this paper}

Please note that where the full-text provided on Manchester Research Explorer is the Author Accepted Manuscript or Proof version this may differ from the final Published version. If citing, it is advised that you check and use the publisher's definitive version.

\section{General rights}

Copyright and moral rights for the publications made accessible in the Research Explorer are retained by the authors and/or other copyright owners and it is a condition of accessing publications that users recognise and abide by the legal requirements associated with these rights.

\section{Takedown policy}

If you believe that this document breaches copyright please refer to the University of Manchester's Takedown Procedures [http://man.ac.uk/04Y6Bo] or contact uml.scholarlycommunications@manchester.ac.uk providing relevant details, so we can investigate your claim.

\section{OPEN ACCESS}


Article Type: Original Article

\title{
Do analysts' cash flow forecasts improve their target price accuracy? ${ }^{1}$
}

\author{
Noor A. Hashim \\ Lancaster University Management School ${ }^{2}$
}

Norman C. Strong ${ }^{3}$

Alliance Manchester Business School ${ }^{4}$

\begin{abstract}
The literature on the usefulness of analysts' cash flow forecasts is unsettled, with Call et al. (2009), Mohanram (2014), and Radhakrishnan and Wu (2014) providing evidence in favor of their usefulness, and Givoly et al. (2009), Bilinski (2014), and Ecker and Schipper (2014) questioning this. Target prices provide a good setting to test the usefulness of cash flow forecasts because they are an ultimate output of an analyst's valuation process to which cash flow forecasts are an input. Moreover, studying the effect of cash flow forecasts on target prices is more relevant for assessing their usefulness than is studying their effect on earnings forecast accuracy, as the accuracy of target prices requires a comparison with market prices, which are less subject to management influence than reported earnings. By improving an analyst's understanding of unexpected accruals and permanent earnings, a cash flow forecast can increase an analyst's target price accuracy and signal an analyst's superior forecasting ability. We examine whether, conditional on their earnings forecasts, analysts' cash flow forecasts improve their target price accuracy. We find that when analysts issue cash flow forecasts, their target price accuracy increases. We also find that this accuracy increases with the accuracy of their cash
\end{abstract}

\footnotetext{
${ }^{1}$ Accepted by Partha S Mohanram. We would like to thank Michael Welker, Partha Mohanram, two anonymous referees, Pawel Bilinski, Sunhwa Choi, Igor Goncharov, Linda Myers, Ken Peasnell, Martin Walker, and Steven Young for several very useful comments and suggestions. Previous versions of this paper had the titles "Analyst Target Price Accuracy and the Incidence of Cash Flow Forecasts" and "Do Analysts Use Their Cash Flow Forecasts When Setting Target Prices." This paper draws on a chapter in Hashim's PhD thesis at the University of Manchester entitled "Three Essays on Analyst Target Prices."

${ }^{2}$ Lancaster University, Bailrigg, Lancaster LA1 4YX, United Kingdom.

${ }^{3}$ Corresponding author: Tel: +441612754006; Fax: +44 1612754023; Email: norman.strong@ manchester.ac.uk

${ }^{4}$ University of Manchester, Booth Street West, Manchester M15 6PB, United Kingdom.

This is an Accepted Article that has been peer-reviewed and approved for publication in the Contemporary Accounting Research, but has yet to undergo copy-editing and proof correction. Please cite this article as an "Accepted Article"; doi: 10.1111/1911-3846.12369

This article is protected by copyright. All rights reserved.
} 
flow forecasts. Finally, we find that this increased target price accuracy is greater for more challenging-to-value firms. Our study provides confirmatory evidence of the usefulness of analysts' cash flow forecasts.

Keywords: Analysts, cash flow forecasts, target price accuracy, valuation.

JEL Classification: M41, G12, G24, G29, C35

\section{Introduction}

A tension exists in the literature over whether analysts' cash flow forecasts are sophisticated or not. ${ }^{5}$ Call et al. (2009) find that analysts' earnings forecasts are more accurate when they also issue cash flow forecasts. Mohanram (2014) and Radhakrishnan and Wu (2014) show that the increasing incidence of cash flow forecasts has helped mitigate accruals mispricing, suggesting that analysts' cash flow forecasts enable investors to price stocks more accurately. ${ }^{6}$ In contrast, Bilinski (2014) finds that analysts are unlikely to issue cash flow forecasts when firms' earnings quality is low, which suggests that Call et al.'s (2009) finding is not evidence of cash flow forecast usefulness but rather the result of analysts making cash flow forecasts only when earnings quality is high. Bilinski's finding also means that analysts issue cash flow forecasts when accruals are easier to estimate, suggesting that cash flow forecasts are of little use for valuation. Givoly et al. (2009) find that, relative to earnings forecasts, analysts revise cash flow forecasts less frequently and their cash flow forecasts are less accurate. Finally, Ecker and Schipper (2014) argue that cash flow forecast firms may never have driven the accruals anomaly and may therefore not drive the results of Mohanram (2014) and Radhakrishnan and Wu (2014).

In this paper, we test the usefulness of analysts' cash flow forecasts by examining whether they improve analysts' target price accuracy. Target prices provide a good setting for testing the

\footnotetext{
${ }^{5}$ Mangen (2013) observes that research on cash flow forecasts and their sophistication is still in its infancy.

${ }^{6}$ Shi et al. (2014) report similar results.
}

This article is protected by copyright. All rights reserved. 
usefulness of cash flow forecasts. Brown et al.'s (2015) conclusion that earnings forecasts are "often a means to an end and not ends in themselves" suggests that analysts place more weight on their valuation outputs than their valuation inputs. Examining whether cash flow forecasts impact target prices directly, therefore, can better confirm their usefulness for valuation independently of their usefulness for earnings forecasts. Studying the effect of cash flow forecasts on target prices is also potentially more relevant for assessing their usefulness than is studying their effect on earnings forecasts. Analysts' target prices are directly comparable to market prices. They provide a direct estimate of analysts' expectations of future stock returns, which earnings forecasts do not. Measuring the accuracy of analysts' earnings forecasts requires a comparison with reported earnings, which are subject to earnings management. Measuring the accuracy of target prices, in contrast, requires a comparison with market prices, which are less subject to management influence. ${ }^{7}$

Research shows that reported cash flows and accounting earnings are each incrementally useful in assessing firm value (e.g., Bowen et al. 1987; Ali 1994; Dechow 1994), but no prior study examines how analysts' cash flow forecasts affect their valuations. While it is difficult to observe analysts' valuation decision processes directly, we can test whether issuing cash flow forecasts affects the quality of their valuations. We hypothesize that an analyst's target price accuracy is higher if the analyst also provides a cash flow forecast, because cash flows are more persistent and therefore more relevant for target prices than are other earnings components. This builds on findings that analysts incorporate less transitory and more persistent earnings components into longer-term earnings forecasts (Mest and Plummer 1999) and that analysts'

\footnotetext{
${ }^{7}$ Mangen (2013) refers to the moving target problem in questioning Call et al.'s (2013) tests of analyst sophistication based on the accuracy of cash flow and accruals forecasts; namely, if firms manage reported cash flows or accruals, forecast accuracy depends on analysts' ability to anticipate this and on their incentives to incorporate it into their forecasts. This problem is less of an issue when comparing target prices with market prices.
}

This article is protected by copyright. All rights reserved. 
long-term earnings forecasts are more relevant than their short-term earnings forecasts for target prices (Bandyopadhyay et al. 1995). We also expect forecasting cash flows to improve target price accuracy, because analysts who issue cash flow forecasts signal their superior ability by forecasting cash flows, which are more difficult to forecast than earnings. Brown et al. (2015) find that analysts consider reported earnings backed by operating cash flows as indicating high earnings quality. Therefore, analysts may disclose cash flow forecasts to indicate the quality of their forecasts. We also build on Mohanram's (2014) finding that there is a direct link between cash flow forecasts and stock prices and suggest that there should be a link between cash flow forecasts and analysts' expectations of future stock prices, that is, target prices. If analysts' cash flow forecasts are sophisticated and contain information incremental to earnings forecasts, target prices should reflect this. In contrast, if analysts' cash flow forecasts are not useful to investors because of their low quality (Givoly et al. 2009) or because analysts issue them only when accruals are easier to estimate (Bilinski 2014), cash flow forecasts may have no effect on the accuracy of analysts' target prices.

Using propensity score matching, we analyze the performance of analysts' target prices accompanied by cash flow forecasts versus those unaccompanied by cash flow forecasts over the sample period 2000-2010. We find that analysts' target price accuracy improves when they accompany their target prices with cash flow forecasts and that their target price accuracy increases with the accuracy of their cash flow forecasts. We also find that this increased accuracy of target prices accompanied by cash flow forecasts is greater for more challenging-to-value firms. Our results suggest that analysts who are better at forecasting cash flows are also better at forecasting target prices, even after controlling for their earnings forecasts, and that analysts' cash flow forecasts contain information incremental to that in their earnings forecasts. A series of

This article is protected by copyright. All rights reserved. 
sensitivity tests confirms the robustness of our findings. Our results have important implications for research on the usefulness of analysts' cash flow forecasts, as they suggest that these forecasts are useful and sophisticated. ${ }^{8}$

Our paper also contributes to the literature on analysts' target prices, which recent studies suggest are under-researched (e.g., Bradshaw et al. 2013). The consistent result from the current literature is the limited accuracy of analysts' target prices compared with their earnings forecasts. ${ }^{9}$ Some studies find larger target price forecast errors are associated with higher target price boldness (Demirakos et al. 2010; Kerl 2011), suggesting that analyst optimism reduces accuracy. Bradshaw et al. (2013) find evidence of persistent differential forecasting ability, but report that the differential abilities are economically trivial. Demirakos et al. (2010) present evidence that analysts select a valuation model appropriate to the difficulty of the valuation task and that accuracy does not vary with valuation model choice after accounting for this. These studies neglect the effect of a fundamental determinant of analysts' forecast quality, namely the quality of their valuation model inputs (Pope 2003). Our study examines the effect of the quality of analysts' cash flow forecasts on their target price accuracy.

Existing evidence on how the quality of valuation inputs affects valuation outcomes is based on earnings forecasts. Gleason et al. (2013) find a substantial reduction in the profitability of target prices derived from a valuation heuristic using inferior earnings forecasts, but there is no corresponding evidence on the effect of cash flow forecasts. Moreover, the literature consistently finds that target prices are less accurate than earnings forecasts (e.g., Asquith et al. 2005;

\footnotetext{
${ }^{8}$ A caveat to our analysis is the assumption that analysts who do not issue cash flow forecasts either do not generate them or at least do not undertake a rigorous, structural articulation of the financial statements to the same extent as analysts who issue cash flow forecasts. While we cannot observe what analysts choose not to publicly disclose, we believe that if analysts generate cash flow forecasts, there is little cost to making them available and little incentive to withhold them.

${ }^{9}$ Asquith et al. (2005) find that 54.3 percent of target prices are met within the following 12 months. Kerl (2011) finds a corresponding target price accuracy of 56.5 percent for German stocks. Bonini et al. (2010) find an accuracy of 33.1 percent for Italian stocks. For U.S. stocks, Bradshaw et al. (2013) report an accuracy of 45 percent.
}

This article is protected by copyright. All rights reserved. 
Bradshaw et al. 2013), and Bradshaw et al. (2013) find that past earnings forecast accuracy is unrelated to target price accuracy. Therefore, while cash flow forecasts may improve earnings forecasts (e.g., Call et al. 2009), they need not necessarily improve target price accuracy. Hence, prior research does not tell us how the quality of cash flow forecasts affects analysts' valuations.

The paper continues as follows. Section 2 develops our research hypotheses. We describe our sample and data in section 3 and research design in section 4 . In sections 5 and 6 , we present sample descriptive statistics, empirical results, and additional analyses. Section 7 concludes.

\section{Research hypotheses}

Financial analysts play a key role in transmitting information to capital markets, and their role has become of increasing interest to regulators and academics. Analysts have begun including cash flow forecasts in their equity reports relatively recently, and their increasing availability has attracted the attention of academic research. ${ }^{10}$ Early research investigated the determinants of investors' demand for cash flow forecasts (DeFond and Hung 2003) and the effect of weak investor protection on cash flow forecast disclosure around the world (DeFond and Hung 2007). Later research has examined the effect of cash flow forecasts on managers' earnings reporting (McInnis and Collins 2011), cash flow forecast availability and analyst earnings forecasts accuracy (Call et al. 2009), the market reaction to firms meeting or beating analysts' cash flow forecasts (Brown et al. 2013), the determinants of cash flow forecast accuracy (Pae and Yoon 2012), and the relation between earnings quality and analysts' decisions to issue cash flow forecasts (Bilinski 2014). Despite the considerable focus on analyst cash flow

\footnotetext{
${ }^{10}$ The frequency of cash flow forecasts accompanying earnings forecasts on $\mathrm{I} / \mathrm{B} / \mathrm{E} / \mathrm{S}$ increased from 1 percent in 1993 to 15 percent in 1999 (DeFond and Hung 2003), to 32 percent in 2005 (Call et al. 2009), and to almost 50 percent by 2010 (Mohanram 2014).
}

This article is protected by copyright. All rights reserved. 
forecasts in the recent literature, there is a lack of information on their usefulness for the ultimate output of analyst research, their valuations in the form of target prices.

There are several reasons why analysts' cash flow forecasts can improve their target price accuracy. First, Mest and Plummer (1999) find that analysts incorporate more persistent earnings components into longer-term earnings forecasts, while Brown et al. (1985) and Bandyopadhyay et al. (1995) find that analysts' long-term earnings forecasts are more relevant than their shortterm earnings forecasts for stock prices and target prices. Separating permanent from transitory earnings components is a key challenge facing analysts (Ramnath et al. 2008). When they forecast cash flows, analysts also forecast accruals, and this process should help them assess the persistence of reported earnings and adjust for transitory earnings components in their valuations. We therefore expect that analysts who issue cash flow forecasts have better information about the magnitude of unexpected accruals and transitory earnings components, which should improve the quality of their valuation inputs and their target price accuracy. ${ }^{11}$

Second, when analysts' issue cash flow forecasts, investors can decompose unexpected earnings into unexpected cash flows and abnormal accruals. McInnis and Collins (2011) show that instances of companies meeting cash flow targets but missing earnings targets are rare, suggesting that the availability of cash flow forecasts does not make firms shift their focus to meeting cash flow targets. Therefore, cash flow forecast availability should help investors assess if firms are manipulating earnings. If cash flow forecast availability reduces earnings management by disciplining managers, it should help investors price stocks more accurately due

\footnotetext{
${ }^{11}$ As part of our analysis, we examine the correlation between analyst accruals forecasts, implicit in their cash flow forecasts, and buy-and-hold stock returns and find a significant positive association (of 2.25 percent). This means that when analysts incorporate their accruals forecasts into their target prices, these target prices should be better forecasts of 12-month-ahead stock prices; this is, at least partly, why target prices should be more accurate when analysts forecast cash flows. We are grateful to the editor for suggesting this analysis.
}

This article is protected by copyright. All rights reserved. 
to an improved information environment. This, in turn, should help to increase the target price accuracy of analysts who make cash flow forecasts available.

Third, Mohanram's (2014) finding of a negative relation between accruals and future returns when analysts provide cash flow forecasts suggests that when analysts provide forecasts of future accruals through their cash flow forecasts, this ameliorates accruals mispricing. Building on Mohanram (2014), we argue that analysts who issue cash flow forecasts possess better information. Since cash flows are more difficult than earnings to predict accurately, analysts who issue cash flow forecasts signal their ability to the market, which their valuations should reflect. This is consistent with Bilinski's (2014) finding that high-quality analysts issue cash flow forecasts to maintain their reputations. Therefore, we hypothesize that target price accuracy improves when analysts supplement their target prices with cash flow forecasts.

Finally, while the literature shows that analysts generally favor earnings-based valuation (Govindarajan 1980; Bradshaw 2002; Demirakos et al. 2004; Asquith et al. 2005), this choice is not absolute. Brown et al. (2015) find that, to support their stock recommendations, while analysts rely on earnings-based valuations, most also frequently use cash flow models, implying that cash flow forecasts are a key factor in analysts' valuation models. DeFond and Hung (2003) find that analysts are more likely to provide cash flow forecasts in industries where earnings forecasts are less informative for valuation. ${ }^{12}$ Demirakos et al. (2010) show that analysts make sophisticated valuation model choices and find that they are more likely to use the discounted cash flow (DCF) model than the price-earnings (P/E) model for more challenging-to-value firms. They conclude that analysts use DCF models more frequently than P/E models when firm characteristics can bias earnings-based valuations. These studies suggest that the role of cash

\footnotetext{
${ }^{12}$ For example, oil and gas analysts rely primarily on operating cash flows when comparing firm performance because they consider earnings unreliable due to differences in the reported earnings of these firms.
}

This article is protected by copyright. All rights reserved. 
flow forecasts in improving target price accuracy does not rely entirely on the relation between cash flow forecasts and earnings forecasts. This leads to our first hypothesis:

HYPOTHESIS 1. An analyst's target price is more accurate if the analyst also provides a cash flow forecast.

We extend this hypothesis by arguing that target prices should reflect not only the presence of cash flow forecasts but also their quality. The process of forecasting target prices is subject to analyst judgment about how a firm creates value and how key value drivers are likely to change in the future. The quality of analysts' valuations should depend on how accurately they translate their forecasts of earnings, cash flows, and other fundamentals into target prices. The available evidence on how analysts' valuation input accuracy affects target price quality is limited to earnings. Bradshaw et al. (2013) find no relation between the past accuracy of analysts' earnings forecasts and target price accuracy. Gleason et al. (2013) find that inferior earnings forecasts reduce the profitability of target prices. Da et al. (2016) find that the investment value of target prices derives in part from analysts' superior ability to forecast earnings. Call et al. (2009) show that the accuracy of analyst earnings forecasts improves in the presence of cash flow forecasts. But there is no evidence on the effect of analyst cash flow forecast quality on target price accuracy. If analysts use cash flow forecasts, either directly or indirectly, as valuation inputs, then the quality of the valuation inputs should affect the quality of their target price valuations. We hypothesize that target price accuracy is higher when cash flow forecast accuracy is higher. Alternatively, cash flow forecast quality may have no effect on target price accuracy if the information contained in cash flow forecasts is not relevant for valuation. Accordingly, we test the following hypothesis:

This article is protected by copyright. All rights reserved. 
HYPOTHESIS 2. An analyst's target price accuracy increases with the accuracy of the analyst's cash flow forecast.

We finally argue that cash flow forecasts contain more relevant information for analyst valuations of more challenging-to-value firms, where earnings are less informative for valuation. This argument derives from evidence in Demirakos et al. (2010) that analysts are more likely to use the DCF model when valuing small firms, high-risk firms, loss-making firms, and firms with a limited number of industry peers, which they use to proxy for more challenging-to-value firms. We predict that the improvement in the accuracy of target prices accompanied by cash flow forecasts is greater for firms that are more challenging to value. Similarly, we predict that the effect of cash flow forecast accuracy on target price accuracy is higher for more challenging-tovalue firms, and we test the following hypotheses:

HYPOTHESIS 3a. The increase in the accuracy of target prices when accompanied by cash flow forecasts is greater for firms that are more challenging to value.

HYPOTHESIS $3 \mathrm{~b}$. The rate at which the accuracy of target prices increases with the accuracy of analysts' cash flow forecasts is greater for firms that are more challenging to value.

\section{Data and sample}

We obtain analyst data on target prices, cash flow forecasts, and earnings forecasts from the I/B/E/S Detail History U.S. Edition database for the period 2000-2010. We focus on one-yearahead forecasts because cash flow forecasts on I/B/E/S are mostly annual. We restrict our analysis to cash flow forecast observations for which target prices and earnings per share

This article is protected by copyright. All rights reserved. 
forecasts are available on I/B/E/S. ${ }^{13}$ We identify two subsamples in our analysis: a) analysts who simultaneously issue cash flow forecasts, earnings forecasts, and target prices; and b) analysts who issue only earnings forecasts and target prices. Observations that have a target price (TP) and a cash flow forecast belong to the CFF sample, while observations that have only a TP belong to the no-CFF sample. We rely on I/B/E/S when determining whether an analyst issues a cash flow forecast for a firm. ${ }^{14}$ To include an observation in the CFF sample, we require the analyst to issue a cash flow forecast on the same day as the target price.

We require observations to have actual earnings and cash flow per share for the year on $\mathrm{I} / \mathrm{B} / \mathrm{E} / \mathrm{S}$ in order to calculate earnings and cash flow forecast accuracy at the analyst level. Additionally, we require observations to have a stock price exceeding $\$ 1$ per share three days before the date of the target price forecast. We also require data on stock price at the end of the forecast horizon (i.e., 12 months after the target price date). ${ }^{15}$ To mitigate the effects of extreme observations due to data errors or misaligned stock spilt factors, we delete the upper 1 percent tail of the distribution of observations based on the ratio of target to actual price. To further eliminate any ambiguity regarding observations in the no-CFF sample, we require that target price observations in the no-CFF sample have no cash flow forecasts on $\mathrm{I} / \mathrm{B} / \mathrm{E} / \mathrm{S}$ by the same analyst for the same firm up to 90 days before the target price announcement date.

For each observation in the CFF sample, we calculate the cash flow forecast error (inverse accuracy) at the analyst level as the absolute value of the difference between the cash flow forecast and the actual cash flow per share as reported by the I/B/E/S Detail History - Actuals

\footnotetext{
${ }^{13}$ We merge cash flow forecast observations with target prices and earnings per share forecasts from the I/B/E/S detail file based on company ticker, estimator ID, analyst mask code, and announcement date.

${ }^{14}$ Call et al. (2009) report that I/B/E/S makes available in its database all cash flow forecasts that analysts provide.

${ }^{15}$ Market price data are from CRSP. Financial statement information and footnote data used later in the analysis are from COMPUSTAT.
}

This article is protected by copyright. All rights reserved. 
file for the relevant end of forecast period, divided by stock price at the forecast date. ${ }^{16} \mathrm{We}$ similarly calculate the earnings forecast error at the analyst level as the absolute difference between the analyst's earnings forecast and actual earnings for the year as reported by $\mathrm{I} / \mathrm{B} / \mathrm{E} / \mathrm{S}$, divided by stock price at the forecast date. Consistently, we calculate target price accuracy as the absolute value of the difference between the target price and the stock price at the end of the target price forecast horizon divided by the current market price. ${ }^{17}$ As Demirakos et al. (2010) explain, it is more meaningful to interpret accuracy in terms of the absolute forecast error than the signed forecast error. The signed forecast error can be difficult to interpret depending on whether the target price is above or below the market price. Other measures of target price accuracy such as measuring whether a target price is met within or at the end of the forecast horizon are less consistent with our measures of cash flow and earnings forecast accuracy.

Table 1 provides descriptive statistics on sample size, analyst and brokerage representation, and industry composition. The table shows that the sample represents 4,230 firms, 6,756 security analysts, and 561 research departments, and comprises 408,040 observations. The number of observations including a cash flow forecast is 42,791, comprising about 10 percent of the sample and covering 2,042 firms and 1,729 analysts working for 268 brokerage houses. The number of observations in the CFF sample increases each year, consistent with previous studies. ${ }^{18}$ The proportion of cash flow forecast observations in the total sample increases from 5 percent in 2000, to 12 percent in 2005, and to 14 percent in 2010. The number of firms receiving cash flow forecasts also increases from 11 percent of all firms in the sample in 2000 to 50 percent in 2010.

\footnotetext{
${ }^{16}$ The Appendix provides precise definitions of all the variables in the main analysis.

${ }^{17}$ The literature uses several target price accuracy measures (see, for example, Asquith et al. 2005; Demirakos et al. 2010; Bradshaw et al. 2013; Bonini et al. 2010). We follow Demirakos et al. (2010) in calculating our (inverse) accuracy measure.

${ }^{18}$ The percentage of cash flow forecast observations is lower than in previous literature because we require our sample observations to include a target price issued on the same day as the cash flow forecast. This does not imply that analysts are less likely to issue cash flow forecasts when they publish target prices.
}

This article is protected by copyright. All rights reserved. 
Only 7 percent of all analysts provide cash flow forecasts in 2000, while this percentage increases to 27 percent by 2010 .

\section{Research design}

We want to measure the impact of disclosing a cash flow forecast on an analyst's TP accuracy. Since we do not observe the counterfactual TP accuracy (i.e., the no-cash flow forecast TP accuracy for a cash flow forecast observation), we cannot evaluate the effects of a cash flow forecast by comparing outcome differences for a given treatment. Previous studies suggest that the analyst's decision to provide a cash flow forecast is not random, so the impact of a cash flow forecast on TP accuracy is unlikely to be homogeneous. Estimating this relation using multiple regression analysis depends on the correct specification of the relation between TP accuracy and the explanatory variables. If this relation is misspecified, regression estimates suffer from functional form misspecification and bias. To address this potential functional form misspecification, we use propensity score matching to balance observed differences between the CFF and no-CFF samples (Shipman et al. 2017). We then run a multivariate regression on the matched sample to achieve higher efficiency. This combined analysis should be more robust and has the potential to significantly improve the quality of the results (Rubin 1973).

To compute the propensity scores, we first estimate the probability that a firm-analyst observation includes a cash flow forecast using the following logistic regression,

$$
\begin{aligned}
& \operatorname{Pr}\left(\text { CFF }_{i}=1\right)= \\
& \beta_{0}+\beta_{1} \text { Accrual }_{i}+\beta_{2} \text { AltmanZ }_{i}+\beta_{3} \text { Capital }_{i}+\beta_{4} \text { MCap }_{i}+\beta_{5} \text { EVol }_{i}+\beta_{6} \text { Freq }_{i} \\
& +\beta_{7} \text { Star }_{i}+\beta_{8} \text { InstOwn }_{i}+\beta_{9} \text { nAnal }_{i}+\beta_{10} \text { Lag }_{-} \text {EPSerr }_{i}+\beta_{11} \text { StrBuy }_{i}+\beta_{12} \text { Buy }_{i} \\
& +\beta_{13} \text { Sell }_{i}+\beta_{14} \text { Lev }_{i}+\text { Year fixed effects }+u_{i}
\end{aligned}
$$

The model estimates the conditional probability that a firm-analyst observation includes a cash flow forecast given observable characteristics of the analyst and firm. CFF is a dummy 
variable that indicates whether observation $i$ includes a cash flow forecast alongside the analyst's target price and earnings forecast. ${ }^{19}$ The explanatory variables are the covariates determining the analyst's decision to forecast cash flows. The first set of explanatory variables follows DeFond and Hung's (2003) investor demand hypothesis. The magnitude of accruals (Accruals) captures the degree of earnings uncertainty. Because accruals are based on managerial estimates, large accrual-based earnings increase market suspicion. ${ }^{20}$ The availability of cash flow information helps validate whether large earnings are consistent with operating cash flows or whether they are financially engineered. Hence, cash flow forecasts should be more valuable for interpreting the information in earnings in the presence of large accruals. Altman's Z-score (AltmanZ) measures a firm's financial health, where lower Z-scores indicate worse financial health (Altman 1968). Cash flow forecasts provide information on liquidity, solvency, and credit and bankruptcy risks. Therefore, cash flow forecasts should be more important for assessing the value of firms in worse financial health. Capital intensity (Capital) is the level of fixed assets in a firm. When capital intensity is high, firms rely on operating cash flows to fund the maintenance and replacement of assets. Cash flow forecasts should be more useful for firms with high capital intensity to assess their ability to meet cash needs. The natural logarithm of the firm's equity market value (MCap) controls for a firm's information environment. Earnings volatility $(E V o l)$ is a measure of earnings quality; when earnings volatility is high, investors perceive earnings

\footnotetext{
${ }^{19}$ Our definition of the cash flow forecast dummy differs from Call et al.'s (2009) definition. Call et al. (2009) define cash flow forecast as a dummy variable that equals one if an analyst issues both cash flow and earnings forecasts for a company in a year, and equals zero if the analyst only issues earnings forecasts for the company in that year. In our definition, we require an observation to have a target price, an earnings forecast, and a cash flow forecast, all issued on the same date by the same analyst to include it in the CFF sample.

${ }^{20}$ We follow DeFond and Hung (2003) in measuring accruals as an absolute value. This is because we are interested in the association between an analyst's incentive to disclose a cash flow forecast and whether net income differs significantly from operating cash flows, regardless of whether the difference is positive or negative. Using a signed accrual measure would result in a different interpretation of the coefficient on the accruals variable. A signed accrual does not capture the size of managerial bias as it treats observations with large negative accruals differently from observations with large positive accruals.
}

This article is protected by copyright. All rights reserved. 
quality to be low and the market requires additional information to assess the persistence of earnings components.

The second set of explanatory variables controls for analyst characteristics. We include variables related to analyst incentives: analyst forecasting frequency (Freq), an Institutional Investor Star analyst dummy (Star), institutional ownership (InstOwn), and the number of analysts following the firm (nAnal). Analysts who make more frequent revisions are less likely to herd (Clement and Tse 2005; Jegadeesh and Kim 2010). ${ }^{21}$ The literature uses the Star analyst ranking to proxy for analyst quality and reputation. Previous research shows a positive relation between forecast accuracy and analyst reputation (Stickel 1992). Institutional ownership in a firm and analyst following provide measures of a firm's information environment. Analysts are also less likely to bias their forecasts for stocks that are highly visible to institutional investors. We expect analysts' past earnings forecast errors (Lag_EPSerr) to affect their decision to issue cash flow forecasts. Building on the demand hypothesis, we expect analysts to provide cash flow forecasts when earnings are more difficult to forecast.

We include stock recommendation categories (StrBuy, Buy, and Sell) to control for the sensitivity of analysts' decisions to issue cash flow forecasts to their recommendations. We include leverage (Lev) to control for a firm's financial structure. Finally, we include year fixed effects to control for any temporal factors that affect all firm-analyst observations in a given year.

\footnotetext{
${ }^{21}$ Evgeniou et al. (2012) show that low-ability analysts tend to herd when information uncertainty is low, while they deviate significantly from the consensus when information uncertainty is high. In contrast, high-ability analysts tend not to change their degree of deviation from the consensus when information uncertainty is high. Evgeniou et al. (2012) suggest that low-ability analysts are willing to take a risk when information uncertainty is high because highability analysts are also likely to have high forecast errors due to the uncertain information environment.
}

This article is protected by copyright. All rights reserved. 
We match cash flow forecast to no-cash flow forecast observations based on the estimated propensity score. We then estimate the following multivariate regression of the effect of an analyst issuing a cash flow forecast for a firm on TP accuracy on the matched sample:

$$
\begin{aligned}
& \text { TPerr }_{i}= \\
& \beta_{0}+\beta_{1} \text { CFF }_{i}+\beta_{2} \text { Accrual }_{i}+\beta_{3} \text { AltmanZ }_{i}+\beta_{4} \text { Capital }_{i}+\beta_{5} \text { MCap }_{i}+\beta_{6} \text { EVol }_{i} \\
& +\beta_{7} \text { Freq }_{i}+\beta_{8} \text { Star }_{i}+\beta_{9} \text { InstOwn }_{i}+\beta_{10} \text { Anal }_{i}+\beta_{11} \text { EPSerr }_{i}+\beta_{12} \text { StrBuy }_{i} \\
& +\beta_{13} \text { Buy }_{i}+\beta_{14} \text { Sell }_{i}+\beta_{15} \text { Lev }_{i}+\text { Fixed effects }+u_{i}
\end{aligned}
$$

The dependent variable is our measure of inverse target price accuracy (TPerr). The main parameter of interest in this model is $\beta_{1}$; our first hypothesis predicts that if target price observations with cash flow forecasts are more accurate, we should observe a negative coefficient on the CFF dummy. A negative coefficient suggests that target price error is lower for observations that have analyst cash flow forecasts compared with the target price error of observations with no cash flow forecasts. The right-hand side of equation (2) includes controls for variables affecting the analyst's decision to issue cash flow forecasts that we discuss above. To control for the effect of earnings forecast quality on target price accuracy, we include EPSerr, the analyst's concurrent earnings per share forecast error. In this, and in all subsequent regressions unless otherwise indicated, we include analyst, firm, and year fixed effects and calculate $p$-values based on standard errors clustered by analyst and firm.

To test our second hypothesis of whether cash flow accuracy is associated with analyst target price accuracy, we estimate the following multivariate regression of target price accuracy on cash flow forecast accuracy on the sample of analyst observations that include a cash flow forecast:

This article is protected by copyright. All rights reserved. 


$$
\begin{aligned}
& \text { TPerr }_{i}= \\
& \beta_{0}+\beta_{1} \text { CFFerr }_{i}+\beta_{2} \text { Accrual }_{i}+\beta_{3} \text { AltmanZ }_{i}+\beta_{4} \text { Capital }_{i}+\beta_{5} \text { MCap }_{i}+\beta_{6} \text { EVol }_{i} \\
& +\beta_{7} \text { Freq }_{i}+\beta_{8} \text { Star }_{i}+\beta_{9} \text { InstOwn }_{i}+\beta_{10} \text { Lev }_{i}+\beta_{11} \text { EPSerr }_{i}+\beta_{12} \text { StrBuy }_{i} \\
& +\beta_{13} \text { Buy }_{i}+\beta_{14} \text { Sell }_{i}+\beta_{15} \text { Anal }_{i}+\text { Fixed effects }+u_{i}
\end{aligned}
$$

CFFerr is the cash flow forecast error (inverse accuracy). Our second hypothesis predicts a positive coefficient on the cash flow forecast error, indicating that target prices are more accurate when analysts make more accurate cash flow forecasts. The other variables on the right-hand side of equation (3) are the same as the control variables of equation (2).

We next test Hypothesis 3a, that the increase in the accuracy of target prices accompanied by cash flow forecasts is greater for more challenging-to-value firms. We test this hypothesis on the sample of analyst observations that include a cash flow forecast. We introduce a dummy variable, Challenging, which equals one if an observation belongs to the group of firms that are more challenging to value. We follow Demirakos et al. (2010) and define challenging-to-value firms based on firm size, firm risk, profitability, and the number of industry peers. Specifically, challenging-to-value-firms are small (in the lowest quartile of our sample by year), are high risk (earnings volatility in the highest quartile of our sample by year), are loss-making (negative reported earnings), or have five or fewer industry peers according to the Global Industry Classification Standard. We estimate the following equation:

$$
\begin{aligned}
& \text { TPerr }_{i}= \\
& \beta_{0}+\beta_{1} \text { CFF }+\beta_{2} \text { Challenging }_{i}+\beta_{3} \text { CFF } \times \text { Challenging }_{i}+\beta_{4} \text { Accrual }_{i} \\
& +\beta_{5} \text { AltmanZ }_{i}+\beta_{6} \text { Capital }_{i}+\beta_{7} \text { MCap }_{i}+\beta_{8} \text { EVol }_{i}+\beta_{9} \text { Freq }_{i}+\beta_{10} \text { Star }_{i} \\
& +\beta_{11} \text { InstOwn }_{i}+\beta_{12} \text { Anal }_{i}+\beta_{13} \text { EPSerr }_{i}+\beta_{14} \text { StrBuy }_{i}+\beta_{15} \text { Buy }_{i} \\
& +\beta_{16} \text { Sell }_{i}+\beta_{17} \text { Lev }_{i}+\text { Fixed effects }+u_{i}
\end{aligned}
$$

The coefficient on the interaction, $C F F \times$ Challenging, tests whether the improvement in target price accuracy in moving from the no-CFF to the CFF samples is greater for challenging-tovalue firms. A negative coefficient supports our hypothesis that the benefit for target price 
accuracy of analysts issuing cash flow forecasts is greater for challenging firms than for nonchallenging firms.

We finally estimate equation (5) to test Hypothesis 3b, that the effect of cash flow forecast accuracy on the accuracy of target prices is greater for challenging-to-value firms.

$$
\begin{aligned}
& \text { TPerr }_{i}= \\
& \beta_{0}+\beta_{1} \text { CFFerr }+\beta_{2} \text { Challenging }_{i}+\beta_{3} \text { CFFerr } \times \text { Challenging }_{i}+\beta_{4} \text { Accrual }_{i} \\
& +\beta_{5} \text { AltmanZ }_{i}+\beta_{6} \text { Capital }_{i}+\beta_{7} \text { MCap }_{i}+\beta_{8} \text { EVol }_{i}+\beta_{9} \text { Freq }_{i}+\beta_{10} \text { Star }_{i} \\
& +\beta_{11} \text { InstOwn }_{i}+\beta_{12} \text { Anal }_{i}+\beta_{13} \text { EPSerr }_{i}+\beta_{14} \text { StrBuy }_{i}+\beta_{15} \text { Buy }_{i} \\
& +\beta_{16} \text { Sell }_{i}+\beta_{17} \text { Lev }_{i}+\text { Fixed effects }+u_{i}
\end{aligned}
$$

In equation (5), which we estimate on the CFF sample, the coefficient on the interaction, CFFerr $\times$ Challenging, tests whether the improvement in target price accuracy associated with higher cash flow forecast accuracy within the CFF sample is greater for challenging-to-value firms than for non-challenging firms. A positive sign on this coefficient supports our hypothesis that the benefit of cash flow forecast availability for target price accuracy of challenging firms is greater than for non-challenging firms.

\section{Empirical estimation and results}

\section{Univariate analysis}

Table 2 provides summary statistics for the variables in the model for the full sample. The average target price error in our sample is 47 percent, which is comparable to the target price error of 45 percent in Bradshaw et al. (2013). Summary statistics for variables determining cash flow forecast disclosure are consistent with those in DeFond and Hung (2003). Other variables are generally consistent with prior literature. ${ }^{22}$ The summary statistics for all variables in the model raise no concerns for the implementation of the propensity score analysis. ${ }^{23}$

\footnotetext{
${ }^{22}$ Our earnings forecast error (EPSerr) summary statistics differ from Call et al.'s (2013) because Call et al. (2013) scale the absolute difference between the earnings forecast and the actual earnings by the earnings forecast, while
}

This article is protected by copyright. All rights reserved. 
We conduct a univariate analysis of the differences in firm characteristics between observations with and without cash flow forecasts. Table 3, panel A, compares the magnitude of accruals, Z-score, capital intensity, earnings forecast error, earnings volatility, institutional ownership, leverage, market capitalization, number of analysts following, and target price error for the two samples. The table also presents the results of mean and median difference tests between the two samples. On average, analysts issue cash flow forecasts for firms with larger absolute accruals, lower $Z$-scores, higher capital intensity, larger earnings forecast error, higher earnings volatility, and larger market capitalization, consistent with previous findings in the literature. We also find that firms with cash flow forecasts have a larger analyst following and higher leverage and institutional ownership, on average. Moreover, target price accuracy is higher for firms with cash flow forecasts. These significant differences support our argument that an analyst's decision to forecast cash flows is not random. The significant differences in means and medians $(p=0.000)$ between the two samples also justifies our use of matching methods.

We also conduct a univariate analysis of the difference in target price accuracy between observations with high and low cash flow forecast error (inverse accuracy). We classify observations below the 25th percentile of CFFerr as observations with low cash flow forecast error and observations above the 75th percentile as observations with high cash flow forecast error. Table 3, panel B, reports differences in means and medians between the two samples. The average target price error is 0.559 for observations in the high cash flow forecast error group, compared with 0.413 for the low cash flow forecast error group. The difference between the two

we scale by the market price prior to announcement, consistent with how we compute our target price error. Call et al. (2013) do not present summary statistics for their cash flow forecast error variable.

${ }^{23}$ We indicate with an asterisk which variables are winsorized in Table 2 (descriptive statistics). We winsorize these variables at the upper and lower 1 percent levels to reduce outlier effects. We do not winsorize other variables because they do not suffer from outlier problems.

This article is protected by copyright. All rights reserved. 
means is significant, as is the difference in median target price accuracy. This suggests that the unconditional target price accuracy is higher for observations with higher cash flow forecast accuracy. We also test the univariate difference in target price accuracy between observations with above and below mean cash flow forecast error of 0.03 . Table 3 , panel $\mathrm{B}$, shows that observations with above average cash flow forecast error have a mean target price error of 0.547 , while observations with below average cash flow forecast error have a mean target price error of 0.417. Differences in means and medians between the two groups are significant.

According to the correlation matrix of the variables in Table 4, there is a high correlation between firm size and analyst following, as expected. The correlations between other variables do not raise any multicollinearity concerns for the regression analysis. Multicollinearity is not an issue for the propensity score matching estimation because estimating the effects of individual covariates is not its main aim.

\section{Multivariate analysis}

\section{The determinants of cash flow forecast disclosure}

Table 5 reports the results of the logistic regression estimation of equation (1) as well as the marginal effects of the independent variables on the probability of an analyst issuing a cash flow forecast. Consistent with DeFond and Hung (2003) and our univariate analysis, Altman's Z-score is negatively associated with the decision to disclose a cash flow forecast, while absolute accruals, earnings volatility, capital intensity, and size are positively associated with cash flow forecast disclosure, with change in capital intensity and the magnitude of accruals having the greatest impacts. This suggests that analysts disclose cash flow forecasts for firms in weaker 
financial health, with more volatile earnings, higher capital intensity, and larger market capitalization. Moreover, the results indicate that analysts are more likely to provide cash flow forecasts for firms with higher institutional ownership and firms with a higher analyst following (i.e., more visible firms). Analysts are also more likely to provide cash flow forecasts for firms they cover more frequently. There is a negative association between analyst Star ranking and the incidence of a cash flow forecast. A possible explanation is that analysts provide cash flow forecasts when they need to improve their earnings forecasts. If non-Star analysts are more likely to make lower-quality earnings forecasts, then they have greater incentives to supplement their earnings forecasts with cash flow forecasts. Moreover, we find a negative relation between an analyst's past earnings forecast error and cash flow forecast disclosure. This is a result that the literature has not previously examined. It implies that analysts who issue cash flow forecasts have higher past earnings forecast accuracy, consistent with our argument that superior analysts issue cash flow forecasts.

We use the results of the logistic regression to estimate the propensity score for each sample observation. The propensity score is the conditional probability of an analyst providing a cash flow forecast for a particular observation. We use the propensity score to identify matched observations in the CFF and no-CFF samples. ${ }^{24} \mathrm{We}$ then assess the covariate balance between the matched observations using several measures. We conduct $t$-tests of the equality of means in

\footnotetext{
${ }^{24}$ We perform this matching with psmatch2 of Leuven and Sianesi (2003). We implement a 1-to- $N$ matching method to increase matching power since our control observations outnumber our treatment observations (Shipman et al. 2017). The matching is with replacement and imposes common support to ensure that the propensity score of the cash flow forecast observations is not higher than the maximum or lower than the minimum propensity score of the no-cash flow forecast observations. According to Shipman et al. (2017), matching with replacement achieves better-quality matches and reduces bias. However, our results are not sensitive to matching without replacement or without imposing a common support. We do not impose a caliper to restrict the maximum allowable distance between the propensity scores for a successful match. However, we perform a number of tests to check matching quality and covariate balance. We are confident that matching eliminates differences in covariates.
}

This article is protected by copyright. All rights reserved. 
the CFF and no-CFF samples after matching. Untabulated results indicate that the matching algorithm successfully balances all of the covariates; all $t$-tests are insignificant $(p>0.1)$. This is consistent with tests based on the standardized bias and the reduction in bias achieved after matching; the standardized bias is the difference in the sample means of the CFF and no-CFF samples as a percentage of the square root of the average of the sample variances in the two samples. After matching, the bias falls significantly for most covariates. Therefore, the matched sampling methodology helps reduce bias due to observed covariates. We combine this propensity score matching method with regression adjustment as an effective method to ensure that we eliminate differences in the propensity scores while using information about the association between the different covariates and the dependent variable (Shipman et al. 2017).

The effect of cash flow forecast availability on target price accuracy

Table 6 reports the results of estimating equation (2) to test our first hypothesis on the association between cash flow forecast availability and target price accuracy. Column (1) reports the results of an OLS regression without matching or controls for selection bias. The results show no significant association between cash flow availability and target price error, while the effect of earnings forecasts error is significant with a coefficient of $0.716(t=7.55)$. This result based on OLS regression may suffer from functional form misspecification of the correct relation between TP accuracy and the explanatory variables and therefore may be unreliable. To address this, we use the matched sample from the propensity score estimation and combine it with regression adjustment. Column (2) reports the estimation of the model after matching. Combining regression with matching involves two stages. The first stage matches observations from the CFF and no-CFF samples on the propensity score. The second stage involves running the regression after matching. When matching observations, we assign each observation its 
propensity score; the regression then includes the propensity score as a covariate (Austin 2011, 409). This regression-adjusted matching generally produces least biased estimates (Rubin 1973).

The results in column (2) suggest that target price error falls in the presence of cash flow forecasts, even after controlling for the earnings forecast error. The coefficient on $C F F$ is -0.055 $(t=-13.41)$. This suggests that the availability of cash flow forecasts is associated with a reduction in analyst target price forecast error, consistent with our first hypothesis. The coefficients on the other covariates suggest that target price error falls for firms with higher institutional ownership and for larger firms. On the other hand, target price error is higher for Star analysts and when the analyst revises her forecast for a firm more frequently. Target price error is also higher for firms with more volatile and uncertain earnings and a larger analyst following.

The effect of cash flow forecast error on target price accuracy

To test our second hypothesis, we estimate equation (3) on the sample of analyst observations that include a cash flow forecast. When we conduct this estimation the sample size falls to 38,650 observations because out of 42,791 observations in the CFF sample, there are 4,141 observations for which $\mathrm{I} / \mathrm{B} / \mathrm{E} / \mathrm{S}$ does not report an actual cash flow for the forecast period end date. Since we need the actual cash flow to calculate the cash flow forecast error, we eliminate observations with no actual cash flows on $\mathrm{I} / \mathrm{B} / \mathrm{E} / \mathrm{S}$. We choose not to use actual cash flows from COMPUSTAT because Givoly et al. (2009) note discrepancies between the actual cash flows that I/B/E/S and COMPUSTAT report in 96.5 percent of cases. Table 7 presents the results of the estimation. Consistent with our prediction, the coefficient on CFFerr of $0.791(t=$

This article is protected by copyright. All rights reserved. 
15.90) suggests that analysts' target prices are more accurate when accompanied by more accurate cash flow forecasts. ${ }^{25,26}$

The above results offer statistically significant evidence on the usefulness of analysts' cash flow forecasts for target prices. Our results are also economically significant. First, changing $C F F$ from zero to one reduces the mean target price error by 9.4 percent. ${ }^{27}$ Second, a one standard deviation increase in CFFerr increases the target price error by 395.50 basis points and the mean target price error by 7.5 percent. $^{28}$

We reestimate equation (2) using an analyst-specific analysis. We examine the accuracy of target prices by an analyst who issues target prices and cash flow and earnings forecasts for some firms but issues only target prices and earnings forecasts for other firms. We expect target prices accompanied by cash flow forecasts to be more accurate than unaccompanied target prices. This analysis mitigates concerns over the effect of analyst characteristics that might affect forecast accuracy and an analyst's decision to issue a cash flow forecast that our previous analysis does not capture. In Table 8, we estimate equation (2) for each analyst separately, for a total of 6,756 unique regressions. We report the mean coefficients and their corresponding $t$-values. We also report the average adjusted $R^{2}$ across all 6,756 regressions.

\footnotetext{
${ }^{25}$ We repeat the estimation of equation (3), replacing CFFerr with a binary variable that takes the value of one if analyst cash flow forecasts have a forecast error above the average CFFerr, and zero otherwise. The results are consistent with those in Table 7, suggesting that observations with above average cash flow forecast errors have higher target price forecast errors.

${ }^{26}$ In an untabulated analysis, we derive actual and forecast accruals per share from actual and forecast earnings and cash flows, calculate accruals per share forecast error (AcFerr) and add this variable to our regression to include all three forecast errors (EPSerr, CFerr, AcFerr). Our main analysis holds, and the results are both statistically and economically significant. The coefficient on CFFerr is also significantly higher than that on either EPSerr or AcFerr. We conclude that cash flow forecasts have a direct effect on target price accuracy and not only because they are a component of analyst earnings forecasts.

${ }^{27}$ The elasticity is the regression coefficient on the cash flow forecast dummy in Table 6, column (2), divided by the mean target price accuracy in Table 2 .

${ }^{28}$ Multiplying the coefficient on CFFerr in Table 7 by the standard deviation of target price accuracy from Table 2 equals 395.50, expressed in basis points. Dividing this by the standard deviation of target price forecast accuracy (times 10,000) yields 7.5 percent.
}

This article is protected by copyright. All rights reserved. 
The mean coefficient on $C F F$ is significantly negative $(-0.070, t=-16.80)$. This suggests that, relative to unaccompanied target prices, when analysts accompany their target prices with cash flow forecasts, their target prices error falls on average by 14.9 percent. This result is consistent with our pooled cross-sectional analysis and suggests that analysts issue more accurate target prices when they also issue cash flow forecasts. ${ }^{29}$ Call et al. (2009) perform an analysis with a similar design to examine the association between cash flow forecast availability and earnings forecast accuracy. They find that relative to analysts who make no cash flow forecasts, the earnings forecasts of analysts who also issue cash flow forecasts are on average 5 percent more accurate.

\section{Target price accuracy of firms that are more challenging to value}

To test Hypothesis 3a, we estimate equation (4) on the matched sample. Table 9, column (1), presents the results. The coefficient on $C F F$ is negative $(-0.038, t=-8.10)$ suggesting that cash flow forecast availability reduces target price error for non-challenging-to-value firms. Table 9 also shows that the coefficient on the interaction term $C F F \times$ Challenging is negative $(-0.020, t=$ -3.68). This implies that the increase in accuracy of target prices accompanied by cash flow forecasts over target prices without cash flow forecasts is greater for challenging-to-value firms than for non-challenging firms. This evidence supports Hypothesis 3a.

Table 9, column (2), presents the results of estimating equation (5) on the CFF sample to test Hypothesis 3b. The coefficient on CFFerr is positive $(0.353, t=4.95)$ suggesting that target price error increases with cash flow forecast error for non-challenging-to-value firms. The coefficient on the interaction term CFFerr $\times$ Challenging is positive $(0.763, t=8.60)$. Consistent

\footnotetext{
${ }^{29}$ We repeat the analysis requiring an analyst to provide a cash flow forecast for at least one of the companies she covers in a year in order to include her in this analysis and find that our results also hold.
}

This article is protected by copyright. All rights reserved. 
with the prediction of Hypothesis $3 \mathrm{~b}$, the association between target price error and cash flow forecast error is larger for firms that are more challenging to value.

\section{Target price accuracy of analysts who switch cash flow disclosure}

Motivated by Call et al. (2009), we use an interrupted time-series specification to estimate the effect of cash flow forecast availability on target price accuracy of a subsample of analysts who initiate the provision of cash flow forecasts for a firm. For this analysis, we retain only one observation for each analyst-firm pair in a year and estimate equation (2), including observations only for the year before and the year of the provision switch for each pair. We identify 2,066 cases (for 512 analysts) representing a switch from provision to non-provision of a cash flow forecast. The results (not tabulated) give an insignificant coefficient on $C F F$ of $-0.032(t=$ -1.15). When, like Call et al. (2009), we restrict this sample to observations for which the analyst continues to provide cash flow forecasts for more than one future year, the number of switches reduces to 519 by 172 analysts. Repeating the regression on this sample gives a significant coefficient on $C F F(-0.157, t=2.69)$, whereas the coefficient on $C F F$ for the "oneoff" switchers remains insignificant at $-0.043(t=-0.57)$. These results suggest that analysts who switch from not providing cash flow forecasts for the firm to providing a cash flow forecast, improve their target price accuracy only when they continue to provide cash flow forecasts in later years. ${ }^{30}$

\footnotetext{
${ }^{30}$ Estimating equivalent regressions on samples of analysts who cease providing cash flow forecasts gives insignificant coefficients on $C F F$. These regressions and those we refer to in the main text in this subsection have much lower sample sizes compared with Call et al. (2009) due to our requirement for observations to have target prices.
}

This article is protected by copyright. All rights reserved. 


\section{Additional analysis}

We undertake several sensitivity tests of our Hypotheses 1 and 2 and report the results in Table $10 .{ }^{31}$ Bradshaw et al. (2013) find that target prices tend to be more accurate in up than down markets. We test the sensitivity of our results to this control. Similar to Bradshaw et al. (2013), we use the sign of the realized S\&P 500 return over the forecast horizon to classify up and down markets. Up markets span the second halves (July-December) of 2002-2006, 2008, and 2009. All other periods are down markets. We add the variable $U p$, which takes the value of one for up markets and zero otherwise, to equations (2) and (3). Consistent with previous findings, $U p$ is negatively associated with target price error, confirming evidence that target price error is lower during up markets. However, the results do not affect the sign or magnitude of the coefficients on our main variables, $C F F$ and $C F F$ err, in equations (2) and (3) (Table 10, columns 1-2). We also test the sensitivity of our results to controlling for temporal effects and for previous findings that cash flow forecast accuracy declines over time. In addition to the year fixed effects that we include in all of our main estimations, we introduce two control variables HorizonCF for cash flows and HorizonTP for target prices, where Horizon equals the number of months to the end of the forecast period. Adding these two control variables and reestimating equation (3) does not affect our results, and HorizonCF and HorizonTP have insignificant coefficients since we already control for year fixed effects (Table 10, column 3).

We also test the sensitivity of our results to alternative explanations for why analysts issue cash flow forecasts. Givoly et al. (2009) challenge the validity of DeFond and Huang's (2003) demand hypothesis. Our paper does not set out to test the demand hypothesis; rather, we use the

\footnotetext{
${ }^{31}$ Table 10 reports the coefficients and $t$-values corresponding to $C F F$ and $C F F$ err for the sensitivity tests we conduct. All estimations, however, include the covariates in our preceding analysis from equations (2) and (3). Regressions involving $C F F$ are on the matched sample and include the propensity score as a covariate.
}

This article is protected by copyright. All rights reserved. 
results from the demand hypothesis only to identify control variables that, based on theory, are likely to affect the analyst's decision to report a cash flow forecast. Table 5 shows that all the demand hypothesis variables are significant, so the choice to include a cash flow forecast or not appears to have a rational theoretical underpinning. Givoly et al., however, argue that market demand may not be the major reason for the increasing availability of cash flow forecasts. For example, they point out a strong industry concentration in the availability of cash flow forecasts, with the energy industry having the highest concentration. We examine whether removing observations from the energy sector affects our tests of Hypotheses 1 and 2 to check if this industry drives our results. Doing this does not change the results we report in the main analysis (Table 10, columns 4-5).

In addition to the above concerns, Givoly et al. (2009) argue that the availability of cash flow forecasts simply follows an upward time trend. We therefore test whether our results hold if we estimate our regressions on three samples: the first covers 2000 to 2003, during which there are fewer cash flow forecast observations than in later periods. The second covers 2004 to 2006, and the third covers 2007 to 2010 . We find consistent results, with the coefficients on $C F F$ and CFFerr having the same signs as the estimation on the full sample (Table 10, columns 6-11). This indicates that changes occurring over time do not drive our results.

The analysis to this point compares analyst target price accuracy accompanied or unaccompanied by a cash flow forecast. However, there are instances when an analyst provides a target price unaccompanied by a cash flow forecast but for a firm that has cash flow forecasts by other analysts in the forecast period. We therefore test the sensitivity of our results to the availability of cash flow forecasts by other analysts for a particular firm. We add the control variable Other-CFF, which takes the value of one if a firm for a particular observation receives 
cash flow forecasts by another analyst in the forecast period, and zero otherwise. This additional control provides insights into whether the target price accuracy of analysts who do not issue cash flow forecasts benefit from the availability of other analysts' cash flow forecasts. It also controls for evidence on the effect of general cash flow forecast availability in correcting mispricing (Mohanram 2014; Radhakrishnan and Wu 2014). We find that our main results are unaffected by including this additional control variable. The results (not tabulated) remain significant after matching and have the expected sign and magnitude. The control Other-CFF has a significant negative coefficient, indicating that the availability of cash flow forecasts by other analysts provides additional improvement in analyst target price accuracy.

\section{Conclusion}

Our study presents evidence that the issuing of cash flow forecasts by analysts has positive capital market consequences. We investigate whether analysts' cash flow forecasts are useful for their valuations. Our results show that cash flow forecasts have the ability to capture and reflect a company's future performance. While analysts' decision processes and how they perform their analysis and estimate target prices are unobservable, our study explores the effect of analyst cash flow forecasts as a valuation input on target prices. We investigate whether analysts' target prices are more accurate when they issue cash flow forecasts than when they do not. Additionally, we predict that an analyst's target price accuracy is higher when the analyst discloses a more accurate cash flow forecast. We model the relation between analyst target price accuracy and cash flow forecast disclosure and also between target price accuracy and cash flow forecast quality. We analyze a sample of U.S. stocks with target prices and cash flow forecasts on I/B/E/S between 2000 and 2010 and find a positive association between analysts' cash flow disclosure and target price accuracy. The effect of cash flow forecast availability on target price 
accuracy is significantly larger for higher quality cash flow forecasts. Our results also show that the increase in target price accuracy when analysts make cash flow forecasts is greater for firms that are more challenging to value. Consistently, we find that the rate at which the accuracy of target prices increase with the accuracy of the analysts' cash flow forecast is greater for firms that are more challenging to value.

Our study is the first to examine the effect of cash flow disclosure and quality on target price accuracy and contributes to our understanding of the link between cash flow forecast disclosures and target prices. Forecasting cash flows can be a sophisticated process. Studying the implications of this process for valuation is essential to understanding how analysts, as financial intermediaries, perform their job of facilitating the flow of information to the capital market. Awareness of how the quality of valuation model inputs affects analysts' stock valuations is of interest to a broad audience of investors, companies, researchers, and analysts.

\section{References}

Ali, A., 1994. The incremental information content of earnings, working capital from operations, and cash flows. Journal of Accounting Research 32, 61-74.

Altman, E. I., 1968. Financial ratios, discriminant analysis and the prediction of corporate bankruptcy. Journal of Finance 23, 589-609.

Asquith, P., Mikhail, M. B., Au, A. S., 2005. Information content of equity analyst reports. Journal of Financial Economics 75, 245-282.

Austin, P.C., 2011. An introduction to propensity score methods for reducing the effects of confounding in observational studies. Multivariate Behavioural Research 46, 399-424.

Bandyopadhyay, S. P., Brown, L. D., Richardson, G. D., 1995. Analysts use of earnings forecasts in predicting stock returns: Forecast horizon effects. International Journal of Forecasting 11, 429-445.

Bilinski, P. 2014. Do analysts disclose cash flow forecasts with earnings estimates when earnings quality is low? Journal of Business Finance and Accounting 41, 401-434.

This article is protected by copyright. All rights reserved. 
Bonini, S., Zanetti, L., Bianchini, R., Salvi, A., 2010. Target price accuracy in equity research. Journal of Business Finance and Accounting 37, 1177-1217.

Bowen, R. M., Burgstahler, D., Daley, L. A., 1987. The incremental information content of accruals versus cash flows. The Accounting Review 62, 723-747.

Bradshaw, M. T., 2002. The use of target prices to justify sell-side analysts' stock recommendations. Accounting Horizons 16, 27-41.

Bradshaw, M. T., Brown, L. D., Huang, K., 2013. Do sell-side analysts exhibit differential target price forecasting ability? Review of Accounting Studies 18, 930-955.

Brown, L.D., Call, A.C., Clement, M.B., Sharp, N.Y. 2015. Inside the 'black box' of sell-side financial analysts. Journal of Accounting Research 53, 1-47.

Brown, L.D., Huang, K., Pinello, A.S. 2013. To beat or not to beat? The importance of analysts' cash flow forecasts. Review of Quantitative Finance and Accounting 41, 723-752.

Brown, P., Foster, G., Noreen, E.W., 1985. Security analyst multi-year earnings forecasts and the capital market. Studies in Accounting Research, 21, American Accounting Association. Sarasota, Florida.

Call, A. C., Chen, S., Tong, Y. H., 2009. Are earnings forecasts accompanied by cash flow forecasts more accurate? Review of Accounting Studies 14, 358-391.

Call, A.C., Chen, S., Tong, Y.H., 2013. Are analysts' cash flow forecasts naive extensions of their own earnings forecasts? Contemporary Accounting Research 30, 438-465.

Clement, M., and Tse, S. 2005. Financial analyst characteristics and herding behavior in forecasting. Journal of Finance, 60, 307-341.

Da, Z., Hong, K. P., Lee, S. 2016. What drives target price forecasts and their investment value? Journal of Business Finance and Accounting 43, 487-510.

Da, Z., Schaumburg, E., 2011. Relative valuation and analyst target price forecasts. Journal of Financial Markets 14, 161-192.

Dechow, P. M., 1994. Accounting earnings and cash flows as measures of firm performance: The role of accounting accruals. Journal of Accounting and Economics 18, 3-42.

DeFond, M. L., Hung, M., 2003. An empirical analysis of analysts' cash flow forecasts. Journal of Accounting and Economics 35, 73-100.

DeFond, M. L., Hung, M., 2007. Investor protection and analysts' cash flow forecasts around the world. Review of Accounting Studies 12, 377-419.

This article is protected by copyright. All rights reserved. 
Demirakos, E. G., Strong, N. C., Walker, M., 2004. What valuation models do analysts use? Accounting Horizon 18, 221-240.

Demirakos, E. G., Strong, N. C., Walker, M., 2010. Does valuation model choice affect target price accuracy? European Accounting Review 19, 35-72.

Ecker, F. and Schipper, K., 2014. Discussion of "Analysts' cash flow forecasts and the decline of the accruals anomaly" and "Analysts' cash flow forecasts and accrual mispricing." Contemporary Accounting Research 31, 1171-1190.

Evgeniou, T., Fang, L., Hogarth, R., Karelaia, N., 2012. Competitive dynamics in forecasting: The interaction of skill and uncertainty. Journal of Behavioral Decision Making 26, 375384.

Givoly, D., Hayn, C., Lehavy, R., 2009. The quality of analysts' cash flow forecasts. The Accounting Review 84, 1877-1911.

Gleason, C. A., Johnson, W. B., Li, H., 2013. Valuation model use and the price target performance of sell-side equity analysts. Contemporary Accounting Research 30, 80-115.

Govindarajan, V., 1980. The objectives of financial statements: An empirical study of the use of cash flow and earnings by security analysts. Accounting Organisation and Society 5, 383392.

Jegadeesh, N., and Kim, W. 2010. Do analysts herd? An analysis of recommendations and market reactions. Review of Financial Studies, 23, 901-937.

Kerl, A. G., 2011. Target price accuracy. Business Research 4, 74-96.

Leuven, E., and Sianesi, B., 2003. Psmatch2: Stata module to perform full Mahalanobis and propensity score matching, common support graphing, and covariate imbalance testing. http://ideas.repec.org/c/boc/bocode/s432001.html. Version 1.2.3.

Mangen, C. 2013. Discussion of “Are analysts' cash flow forecasts naïve extensions of their own earnings forecasts?" Contemporary Accounting Research 30, 466-481.

McInnis, J. M., Collins, D. W., 2011. The effect of cash flow forecasts on accrual quality and benchmark beating. Journal of Accounting and Economics 51, 219-239.

Mest, D.P., Plummer, E., 1999. Transitory and persistent earnings components as reflected in analysts' short-term and long-term earnings forecasts: evidence from a nonlinear model. International Journal of Forecasting 15, 291-308.

Mohanram, P.S., 2014. Analysts' cash flow forecasts and the decline of the accruals anomaly. Contemporary Accounting Research 31, 1143-1170.

This article is protected by copyright. All rights reserved. 
Pae, J., Yoon, S., 2012. Determinants of analysts' cash flow forecast accuracy. Journal of Accounting, Auditing and Finance 27, 123-144.

Pope, P., 2003. Discussion of disclosure practices, enforcement of accounting standards, and analysts' forecast accuracy: an international study. Journal of Accounting Research, 41, 273-283.

Radhakrishnan, S., Wu, S. 2014. Analysts' Cash flow forecasts and accrual mispricing. Contemporary Accounting Research 31, 1191-1219.

Ramnath, S., Rock, S., Shane, P., 2008. The financial analyst forecasting literature: A taxonomy with suggestions for further research. International Journal of Forecasting 24, 34-75.

Rubin, D.B., 1973. The use of matched sampling and regression adjustment to remove bias in observational studies. Biometrics 29, 185-203.

Shi, L., Zhang, H., Guo, J., 2014. Analyst cash flow forecasts and pricing of accruals. Advances in Accounting 30, 95-105

Shipman, J.E., Swanquist, Q.T., Whited, R.L., 2017. Propensity score matching in accounting research. The Accounting Review 92, 213-244.

Stickel, S. 1992. Reputation and performance among security analysts. Journal of Finance, 47, 1811-1836.

This article is protected by copyright. All rights reserved. 
TABLE 1

Descriptive statistics for sample size and analyst and research department representation

\begin{tabular}{lrrr}
\hline & Full sample & CFF sample & No-CFF sample \\
\hline Companies & 4,230 & 2,042 & 4,212 \\
Analysts & 6,756 & 1,729 & 6,613 \\
Research departments & 573 & 268 & 561 \\
Observations & 408,040 & 42,791 & 365,249 \\
\hline
\end{tabular}

\begin{tabular}{|c|c|c|c|c|c|c|c|c|c|}
\hline & \multicolumn{3}{|c|}{ Companies } & \multicolumn{3}{|c|}{ Analysts } & \multicolumn{3}{|c|}{ Observations } \\
\hline Year & $\begin{array}{c}\text { Full } \\
\text { sample }\end{array}$ & $\begin{array}{c}\text { CFF } \\
\text { sample }\end{array}$ & $\begin{array}{c}\text { No- } \\
\text { CFF } \\
\text { sample }\end{array}$ & $\begin{array}{c}\text { Full } \\
\text { sample }\end{array}$ & $\begin{array}{c}\mathrm{CFF} \\
\text { sample }\end{array}$ & $\begin{array}{c}\text { No- } \\
\text { CFF } \\
\text { sample }\end{array}$ & $\begin{array}{c}\text { Full } \\
\text { sample }\end{array}$ & $\begin{array}{c}\mathrm{CFF} \\
\text { sample }\end{array}$ & $\begin{array}{l}\text { No-CFF } \\
\text { sample }\end{array}$ \\
\hline 2000 & 1,920 & 211 & 1,914 & 1,985 & 134 & 1,967 & 18,306 & 860 & 17,446 \\
\hline 2001 & 1,877 & 131 & 1,875 & 2,152 & 117 & 2,147 & 22,771 & 543 & 22,228 \\
\hline 2002 & 1,892 & 188 & 1,889 & 2,292 & 165 & 2,284 & 28,319 & 844 & 27,475 \\
\hline 2003 & 1,980 & 612 & 1,975 & 2,062 & 359 & 2,033 & 30,914 & 2,350 & 28,564 \\
\hline 2004 & 2,087 & 735 & 2,067 & 2,196 & 468 & 2,150 & 33,914 & 3,448 & 30,466 \\
\hline 2005 & 2,204 & 847 & 2,186 & 2,199 & 435 & 2,152 & 33,644 & 4,036 & 29,608 \\
\hline 2006 & 2,275 & 917 & 2,252 & 2,223 & 460 & 2,161 & 36,261 & 3,878 & 32,383 \\
\hline 2007 & 2,303 & 951 & 2,280 & 2,255 & 482 & 2,200 & 39,900 & 4,306 & 35,594 \\
\hline 2008 & 2,282 & 1,024 & 2,261 & 2,291 & 507 & 2,219 & 51,827 & 6,611 & 45,216 \\
\hline 2009 & 2,226 & 1,064 & 2,212 & 2,290 & 543 & 2,216 & 53,026 & 7,524 & 45,502 \\
\hline 2010 & 2,225 & 1,115 & 2,209 & 2,571 & 688 & 2,440 & 59,158 & 8,391 & 50,767 \\
\hline
\end{tabular}

Notes: The table presents the sample distribution by cash flow forecast availability for companies, analysts, and research departments and the sample observations by year for the full sample, the cash flow forecast (CFF) sample and the no-cash flow forecast (no-CFF) sample.

This article is protected by copyright. All rights reserved. 
TABLE 2

Descriptive statistics

\begin{tabular}{|c|c|c|c|c|c|c|c|c|}
\hline Variable & $N$ & Mean & Std. Dev. & Min & 25 th & Median & 75th & Max \\
\hline Accrual & 408,040 & 0.09 & 0.13 & 0.00 & 0.03 & 0.06 & 0.10 & 11.45 \\
\hline AltmanZ* & 408,040 & 5.75 & 6.50 & -2.74 & 2.18 & 3.82 & 6.70 & 39.07 \\
\hline Buy & 408,040 & 0.34 & 0.48 & 0.00 & 0.00 & 0.00 & 1.00 & 1.00 \\
\hline Capital* & 408,040 & 0.94 & 1.36 & 0.00 & 0.23 & 0.41 & 0.91 & 7.88 \\
\hline CFFerr* & 38,650 & 0.03 & 0.05 & 0.00 & 0.01 & 0.02 & 0.04 & 0.35 \\
\hline$C F F$ & 408,040 & 0.10 & 0.31 & 0.00 & 0.00 & 0.00 & 0.00 & 1.00 \\
\hline Challenging & 408,040 & 0.42 & 0.49 & 0.00 & 0.00 & 0.00 & 1.00 & 1.00 \\
\hline EPSerr & 408,040 & 0.05 & 0.13 & 0.00 & 0.02 & 0.03 & 0.05 & 21.94 \\
\hline EVol & 408,040 & 2.64 & 1.84 & -4.73 & 1.31 & 2.55 & 3.89 & 11.12 \\
\hline Freq & 408,040 & 4.25 & 2.63 & 1.00 & 2.00 & 4.00 & 5.00 & 33.00 \\
\hline Hold & 408,040 & 0.33 & 0.47 & 0.00 & 0.00 & 0.00 & 1.00 & 1.00 \\
\hline InstOwn & 408,040 & 0.71 & 0.22 & 0.00 & 0.59 & 0.75 & 0.87 & 1.00 \\
\hline Lev & 408,040 & 0.21 & 0.21 & 0.00 & 0.03 & 0.18 & 0.32 & 4.99 \\
\hline Lag_EPSerr & 408,040 & 0.04 & 0.04 & 0.00 & 0.01 & 0.03 & 0.05 & 0.27 \\
\hline MCap & 408,040 & 14.70 & 1.71 & 7.14 & 13.48 & 14.61 & 15.86 & 20.06 \\
\hline nAnal & 408,040 & 13.23 & 7.97 & 1.00 & 7.00 & 12.00 & 18.00 & 53.00 \\
\hline Sell & 408,040 & 0.01 & 0.12 & 0.00 & 0.00 & 0.00 & 0.00 & 1.00 \\
\hline Star & 408,040 & 0.17 & 0.38 & 0.00 & 0.00 & 0.00 & 0.00 & 1.00 \\
\hline StrBuy & 408,040 & 0.26 & 0.44 & 0.00 & 0.00 & 0.00 & 1.00 & 1.00 \\
\hline TPerr* & 408,040 & 0.47 & 0.53 & 0.01 & 0.15 & 0.34 & 0.63 & 11.00 \\
\hline
\end{tabular}

Notes: Summary statistics for all variables in the study. Variables followed by an asterisk are winsorized at the upper and lower 1 percent levels to reduce outlier effects. The Appendix provides variable definitions.

This article is protected by copyright. All rights reserved. 
TABLE 3

Comparison of firm characteristics and of target price accuracy with cash flow forecast accuracy

Panel A: Comparison of firm characteristics

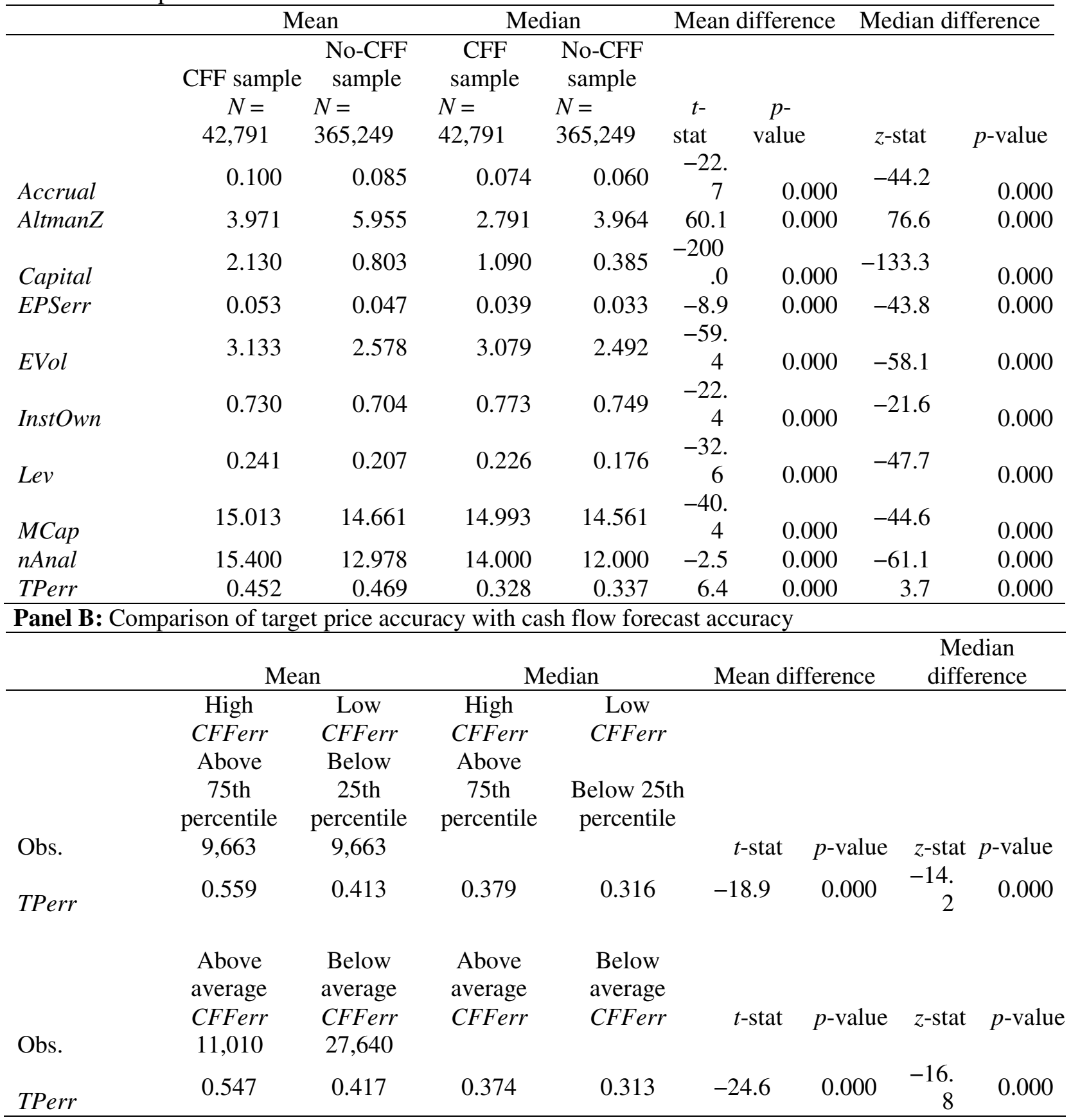

Notes: Panel A compares the characteristics of companies with and without cash flow forecasts, giving the means of firm characteristics and the results of mean and median differences tests. Panel B shows the univariate analysis of the difference in target price accuracy between observations with high vs. low cash flow forecast error (inverse accuracy). High CFFerr denotes observations above the 75th percentile of CFFerr (i.e., observations with high cash flow forecast error). Low CFFerr denotes observations below the 25th percentile of CFFerr (i.e., observations with low cash flow forecast error). Above average CFFerr includes observations with CFFerr larger than the mean. Below average CFFerr includes observations with $C F F e r r$ below the mean. The Appendix provides variable definitions.

This article is protected by copyright. All rights reserved. 
TABLE 4

Pearson correlations between variables

\begin{tabular}{|c|c|c|c|c|c|c|c|c|c|c|c|}
\hline AltmanZ & $\begin{array}{l}\text { Accrual } \\
\quad-0.0757 \\
* *\end{array}$ & AltmanZ & Buy & Capital & CFFerr & $C F F$ & Challenging & EPSerr & EVol & Freq & Hold \\
\hline Buy & 0.0006 & $\begin{array}{l}0.0373 * \\
*\end{array}$ & & & & & & & & & \\
\hline Capital & $\begin{array}{l}0.0819 * \\
*\end{array}$ & $\begin{array}{l}-0.2199 \\
* *\end{array}$ & $\begin{array}{l}0.0158^{*} \\
*\end{array}$ & & & & & & & & \\
\hline CFFerr & $\begin{array}{l}0.0986^{*} \\
*\end{array}$ & $\begin{array}{l}-0.1428 \\
* *\end{array}$ & $\begin{array}{l}-0.0332 \\
* *\end{array}$ & $\begin{array}{l}0.0178 * \\
*\end{array}$ & & & & & & & \\
\hline$C F F$ & $\begin{array}{l}0.0355^{*} \\
*\end{array}$ & $\begin{array}{l}-0.0936 \\
* *\end{array}$ & 0.0026 & $\begin{array}{l}0.2985 * \\
*\end{array}$ & N/A & & & & & & \\
\hline Challenging & $\begin{array}{l}0.1907 * \\
*\end{array}$ & $\begin{array}{l}0.0420 * \\
*\end{array}$ & $\begin{array}{l}0.0035^{*} \\
*\end{array}$ & $\begin{array}{l}0.0185 * \\
*\end{array}$ & $\begin{array}{l}0.1702 * \\
*\end{array}$ & $\begin{array}{l}-0.0554 \\
* *\end{array}$ & & & & & \\
\hline EPSerr & $\begin{array}{l}0.0648 * \\
*\end{array}$ & $\begin{array}{l}-0.0861 \\
* *\end{array}$ & $\begin{array}{l}-0.0181 \\
* *\end{array}$ & $\begin{array}{l}0.0724 * \\
*\end{array}$ & $\begin{array}{l}0.2941 * \\
*\end{array}$ & $\begin{array}{c}0.0139 * \\
*\end{array}$ & $\begin{array}{l}0.0652^{*} \\
*\end{array}$ & & & & \\
\hline EVol & $\begin{array}{c}0.1333 * \\
*\end{array}$ & $\begin{array}{l}-0.2371 \\
* *\end{array}$ & -0.0028 & $\begin{array}{c}0.1488 * \\
*\end{array}$ & $\begin{array}{c}0.0478 * \\
*\end{array}$ & $\begin{array}{l}0.0926 * \\
*\end{array}$ & $\begin{array}{l}-0.4017 \\
* *\end{array}$ & $\begin{array}{c}0.0436 * \\
*\end{array}$ & & & \\
\hline Freq & $\begin{array}{l}-0.0092 \\
* *\end{array}$ & $\begin{array}{l}-0.0463 \\
* *\end{array}$ & $\begin{array}{l}-0.0168 \\
* *\end{array}$ & $\begin{array}{l}0.0566^{*} \\
*\end{array}$ & $\begin{array}{l}0.0169 * \\
*\end{array}$ & $\begin{array}{l}0.0810^{*} \\
*\end{array}$ & $\begin{array}{l}-0.1362 \\
* *\end{array}$ & $\begin{array}{l}0.0101 * \\
*\end{array}$ & $\begin{array}{l}0.1654^{*} \\
*\end{array}$ & & \\
\hline Hold & -0.0026 & $\begin{array}{l}-0.0540 \\
* *\end{array}$ & $\begin{array}{l}-0.4966 \\
* *\end{array}$ & $\begin{array}{l}-0.0184 \\
* *\end{array}$ & $\begin{array}{l}0.0267 * \\
*\end{array}$ & $\begin{array}{l}0.0202 * \\
*\end{array}$ & $\begin{array}{l}-0.0437 \\
* *\end{array}$ & $\begin{array}{l}0.0290 * \\
*\end{array}$ & $\begin{array}{l}0.0630 * \\
*\end{array}$ & $\begin{array}{c}0.0752 * \\
*\end{array}$ & \\
\hline InstOwn & $\begin{array}{l}-0.0561 \\
* *\end{array}$ & $\begin{array}{l}-0.0557 \\
* *\end{array}$ & $\begin{array}{l}-0.0234 \\
* *\end{array}$ & $\begin{array}{l}-0.0859 \\
* *\end{array}$ & $\begin{array}{l}-0.1032 \\
* *\end{array}$ & $\begin{array}{l}0.0351 * \\
*\end{array}$ & $\begin{array}{l}-0.1532 \\
* *\end{array}$ & $\begin{array}{l}-0.0418 \\
* *\end{array}$ & $\begin{array}{l}0.0560 * \\
*\end{array}$ & $\begin{array}{l}0.1153 * \\
*\end{array}$ & $\begin{array}{l}0.0598^{*} \\
*\end{array}$ \\
\hline Lev & $\begin{array}{l}0.0143 * \\
*\end{array}$ & $\begin{array}{l}-0.4315 \\
* *\end{array}$ & $\begin{array}{l}-0.0108 \\
* *\end{array}$ & $\begin{array}{l}0.2780 * \\
*\end{array}$ & $\begin{array}{l}0.1908 * \\
*\end{array}$ & $\begin{array}{l}0.0510 * \\
*\end{array}$ & $\begin{array}{l}-0.0353 \\
* *\end{array}$ & $\begin{array}{l}0.1076^{*} \\
*\end{array}$ & $\begin{array}{l}0.1900 * \\
*\end{array}$ & 0.0023 & $\begin{array}{l}0.0185 * \\
*\end{array}$ \\
\hline Lag_EPSerr & $\begin{array}{l}0.0912 * \\
*\end{array}$ & $\begin{array}{l}-0.1216 \\
* *\end{array}$ & $\begin{array}{l}-0.0144 \\
* *\end{array}$ & $\begin{array}{l}0.0941 * \\
*\end{array}$ & $\begin{array}{l}0.2455^{*} \\
*\end{array}$ & $\begin{array}{l}0.0254 * \\
*\end{array}$ & $\begin{array}{l}0.0709 * \\
*\end{array}$ & $\begin{array}{l}0.4779 * \\
*\end{array}$ & $\begin{array}{l}0.0795^{*} \\
*\end{array}$ & $\begin{array}{l}0.0175 * \\
*\end{array}$ & $\begin{array}{l}0.0273 * \\
*\end{array}$ \\
\hline MCap & $\begin{array}{l}-0.1187 \\
* *\end{array}$ & $\begin{array}{l}0.0041 * \\
*\end{array}$ & $\begin{array}{l}0.0324 * \\
*\end{array}$ & $\begin{array}{l}0.0434 * \\
*\end{array}$ & $\begin{array}{l}-0.2827 \\
* *\end{array}$ & $\begin{array}{l}0.0631 * \\
*\end{array}$ & $\begin{array}{l}-0.5507 \\
* *\end{array}$ & $\begin{array}{l}-0.1283 \\
* *\end{array}$ & $\begin{array}{l}0.6953^{*} \\
*\end{array}$ & $\begin{array}{l}0.1558 * \\
*\end{array}$ & $\begin{array}{l}0.0212 * \\
*\end{array}$ \\
\hline nAnal & $\begin{array}{l}-0.0035 \\
* *\end{array}$ & $\begin{array}{l}0.0687 * \\
*\end{array}$ & $\begin{array}{l}0.0332 * \\
*\end{array}$ & $\begin{array}{l}0.0912 * \\
*\end{array}$ & $\begin{array}{l}-0.1416 \\
* *\end{array}$ & $\begin{array}{l}0.0931 * \\
*\end{array}$ & $\begin{array}{l}-0.3567 \\
* *\end{array}$ & $\begin{array}{l}-0.0552 \\
* *\end{array}$ & $\begin{array}{l}0.5102^{*} \\
*\end{array}$ & $\begin{array}{l}0.1843 * \\
*\end{array}$ & $\begin{array}{l}0.0092 * \\
*\end{array}$ \\
\hline Sell & $\begin{array}{l}0.0061 * \\
*\end{array}$ & $\begin{array}{l}-0.0067 \\
* *\end{array}$ & $\begin{array}{l}-0.0863 \\
* *\end{array}$ & $\begin{array}{l}-0.0038 \\
* *\end{array}$ & $\begin{array}{l}0.0190 * \\
*\end{array}$ & $\begin{array}{l}-0.0167 \\
* *\end{array}$ & 0.0005 & $\begin{array}{l}0.0159 * \\
*\end{array}$ & $\begin{array}{l}0.0153 * \\
*\end{array}$ & $\begin{array}{l}-0.0170 \\
* *\end{array}$ & $\begin{array}{l}-0.0818 \\
* *\end{array}$ \\
\hline Star & $\begin{array}{l}-0.0291 \\
* *\end{array}$ & $\begin{array}{l}-0.0414 \\
* *\end{array}$ & $\begin{array}{l}-0.0153 \\
* *\end{array}$ & $\begin{array}{l}-0.0134 \\
* *\end{array}$ & $\begin{array}{l}-0.0317 \\
* *\end{array}$ & $\begin{array}{l}-0.0209 \\
* *\end{array}$ & $\begin{array}{l}-0.0992 \\
* *\end{array}$ & $\begin{array}{l}-0.0059 \\
* *\end{array}$ & $\begin{array}{l}0.1283 * \\
*\end{array}$ & $\begin{array}{l}0.0584 * \\
*\end{array}$ & $\begin{array}{l}0.0669 * \\
*\end{array}$ \\
\hline StrBuy & -0.0009 & $\begin{array}{l}0.0254 * \\
*\end{array}$ & $\begin{array}{l}-0.4062 \\
* *\end{array}$ & $\begin{array}{l}-0.0037 \\
* *\end{array}$ & $\begin{array}{l}-0.0254 \\
* *\end{array}$ & $\begin{array}{l}-0.0293 \\
* *\end{array}$ & $\begin{array}{l}0.0418 * \\
*\end{array}$ & $\begin{array}{l}-0.0219 \\
* *\end{array}$ & $\begin{array}{l}-0.0727 \\
* *\end{array}$ & $\begin{array}{l}-0.0368 \\
* *\end{array}$ & $\begin{array}{l}-0.4078 \\
* *\end{array}$ \\
\hline TPerr & $\begin{array}{l}0.0990 * \\
*\end{array}$ & $\begin{array}{l}0.0527 * \\
*\end{array}$ & $\begin{array}{l}0.0111 * \\
*\end{array}$ & $\begin{array}{l}0.0551 * \\
*\end{array}$ & $\underset{*}{0.2069 *}$ & $\begin{array}{l}-0.0100 \\
* *\end{array}$ & $\begin{array}{l}0.1674 * \\
*\end{array}$ & $\begin{array}{l}0.2253^{*} \\
*\end{array}$ & $\begin{array}{l}-0.0984 \\
* *\end{array}$ & $\begin{array}{l}-0.0084 \\
* *\end{array}$ & $\begin{array}{l}-0.0592 \\
* *\end{array}$ \\
\hline
\end{tabular}

TABLE 4

Continued

\begin{tabular}{|c|c|c|c|c|c|c|c|c|}
\hline & InstOwn & Lev & Lag_EPSerr & MCap & nAnal & Sell & Star & StrBuy \\
\hline Lev & $-0.0052 * *$ & & & & & & & \\
\hline Lag_EPSerr & $-0.0559 * *$ & $0.1155^{* *}$ & & & & & & \\
\hline MCap & $0.1173^{* *}$ & $0.0164 * *$ & $-0.1041 * *$ & & & & & \\
\hline nAnal & $0.1453^{* *}$ & $-0.0715^{* *}$ & $-0.0571 * *$ & $0.6783^{* *}$ & & & & \\
\hline Sell & 0.0026 & $0.0071^{* *} *$ & $0.0129 * *$ & $-0.0050 * *$ & 0.002 & & & \\
\hline Star & $0.0065^{* *}$ & $0.0646^{* *}$ & $-0.0103^{* *}$ & $0.1443^{* *}$ & $0.0206^{* *}$ & $0.0097 * *$ & & \\
\hline StrBuy & $-0.0203 * *$ & $-0.0234^{* *}$ & $-0.0228 * *$ & $-0.0421^{* *}$ & $-0.0297 * *$ & $-0.0709 * *$ & $-0.0762 * *$ & \\
\hline TPerr & $-0.1265^{* *}$ & $0.0339 * *$ & $0.1172 * *$ & $-0.2498 * *$ & $-0.1028 * *$ & $0.0070^{* * *}$ & $-0.0223 * *$ & $0.0377 * *$ \\
\hline
\end{tabular}

Notes: The table reports Pearson correlations between the variables. The Appendix provides variables definitions. ** indicates a significance level of 0.05 . 
TABLE 5

Propensity score estimation using logistic regression

\begin{tabular}{|c|c|c|c|}
\hline Dependent variable & $\begin{array}{l}\text { Predicted } \\
\text { sign }\end{array}$ & $C F F$ & $\begin{array}{l}\text { Marginal } \\
\text { effect }\end{array}$ \\
\hline \multirow[t]{2}{*}{ Accrual } & + & $0.308 * * *$ & $0.022 * * *$ \\
\hline & & [8.84] & [8.85] \\
\hline \multirow[t]{2}{*}{ AltmanZ } & - & $-0.031 * * *$ & $-0.002 * * *$ \\
\hline & & {$[-21.42]$} & {$[-21.63]$} \\
\hline \multirow[t]{2}{*}{ Capital } & + & $0.448 * * *$ & $0.032 * * *$ \\
\hline & & [131.21] & [118.49] \\
\hline \multirow[t]{2}{*}{ MCap } & + & $0.039 * * *$ & $0.003 * * *$ \\
\hline & & [6.76] & [6.76] \\
\hline \multirow[t]{2}{*}{ EVol } & + & $0.022 * * *$ & $0.002 * * *$ \\
\hline & & {$[4.70]$} & {$[4.70]$} \\
\hline \multirow[t]{2}{*}{ Freq } & + & $0.042 * * *$ & $0.003 * * *$ \\
\hline & & [22.42] & [22.39] \\
\hline \multirow[t]{2}{*}{ Star } & + & $-0.188 * * *$ & $-0.013 * * *$ \\
\hline & & {$[-11.80]$} & {$[-12.46]$} \\
\hline \multirow[t]{2}{*}{ InstOwn } & + & $0.399 * * *$ & $0.029 * * *$ \\
\hline & & [13.98] & [14.02] \\
\hline \multirow[t]{2}{*}{ nAnal } & + & $0.016 * * *$ & $0.001 * * *$ \\
\hline & & [17.12] & [17.18] \\
\hline \multirow[t]{2}{*}{ Lag_EPSerr } & + & $-0.403 * * *$ & $-0.029 * * *$ \\
\hline & & {$[-4.33]$} & {$[-4.33]$} \\
\hline \multirow[t]{2}{*}{ StrBuy } & & $-0.253 * * *$ & $-0.018 * * *$ \\
\hline & & {$[-17.99]$} & {$[-18.89]$} \\
\hline \multirow[t]{2}{*}{ Buy } & & $-0.093 * * *$ & $-0.007 * * *$ \\
\hline & & {$[-7.34]$} & {$[-7.43]$} \\
\hline \multirow[t]{2}{*}{ Sell } & & $-0.688 * * *$ & $-0.049 * * *$ \\
\hline & & {$[-11.76]$} & {$[-16.08]$} \\
\hline \multirow[t]{2}{*}{ Lev } & & $-0.579 * * *$ & $-0.042 * * *$ \\
\hline & & {$[-17.57]$} & {$[-17.64]$} \\
\hline Year fixed effects & & Yes & \\
\hline Pseudo $R^{2}$ & & $13.18 \%$ & \\
\hline Wald $\chi^{2}$ & & $30,715.33$ & \\
\hline Obs. & & 408,040 & \\
\hline
\end{tabular}

Notes: Logistic regression of $C F F$ on variables determining the analyst choice to forecast cash flows and control variables. The regression includes an (unreported) constant. We use the output of this regression, the probability of forecasting cash flows, to calculate the propensity score. We report $z$-values in brackets. *** indicates a significance level of 0.01 . The Appendix provides variable definitions.

This article is protected by copyright. All rights reserved. 
TABLE 6

Estimation of the effect of cash flow forecast availability on target price accuracy

\begin{tabular}{|c|c|c|}
\hline $\begin{array}{l}\text { Dependent variable } \\
\text { TPerr }\end{array}$ & $\begin{array}{l}\text { OLS estimation } \\
\text { (1) }\end{array}$ & $\begin{array}{l}\text { Estimation on the matched sample } \\
\text { (2) }\end{array}$ \\
\hline \multirow[t]{2}{*}{ CFF } & 0.001 & $-0.055^{* * *}$ \\
\hline & {$[0.21]$} & {$[-13.41]$} \\
\hline \multirow[t]{2}{*}{ Accrual } & $0.139 * * *$ & $0.109 * * *$ \\
\hline & {$[5.83]$} & {$[6.43]$} \\
\hline \multirow[t]{2}{*}{ AltmanZ } & $0.006^{* * *}$ & $0.008 * * *$ \\
\hline & {$[16.74]$} & [30.17] \\
\hline \multirow[t]{2}{*}{ Capital } & $0.014 * * *$ & $-0.046 * * *$ \\
\hline & {$[6.70]$} & {$[-11.32]$} \\
\hline \multirow[t]{2}{*}{ MCap } & $-0.114 * * *$ & $-0.119 * * *$ \\
\hline & {$[-44.04]$} & {$[-68.05]$} \\
\hline \multirow[t]{2}{*}{ EVol } & $0.031 * * *$ & $0.029 * * *$ \\
\hline & {$[15.58]$} & {$[24.52]$} \\
\hline \multirow[t]{2}{*}{ Freq } & $0.007 * * *$ & $0.001 * * *$ \\
\hline & [9.13] & {$[2.73]$} \\
\hline \multirow[t]{2}{*}{ Star } & 0.000 & $0.017 * * *$ \\
\hline & {$[-0.05]$} & {$[7.28]$} \\
\hline \multirow[t]{2}{*}{ InstOwn } & $-0.160^{* * *}$ & $-0.198 * * *$ \\
\hline & {$[-18.50]$} & {$[-37.73]$} \\
\hline \multirow[t]{2}{*}{ nAnal } & $0.008 * * *$ & $0.006 * * *$ \\
\hline & {$[25.20]$} & [35.89] \\
\hline \multirow[t]{2}{*}{ EPSerr } & $0.716^{* * *}$ & $0.716^{* * * *}$ \\
\hline & {$[7.55]$} & {$[10.42]$} \\
\hline \multirow[t]{2}{*}{ StrBuy } & $0.055^{* * *}$ & $0.088 * * *$ \\
\hline & [14.34] & [31.41] \\
\hline \multirow[t]{2}{*}{ Buy } & $0.033 * * *$ & $0.045^{* * *}$ \\
\hline & {$[9.82]$} & [23.74] \\
\hline \multirow[t]{2}{*}{ Sell } & $0.055^{* * *} *$ & $0.131 * * *$ \\
\hline & {$[4.25]$} & {$[14.82]$} \\
\hline \multirow[t]{2}{*}{ Lev } & $0.063 * * *$ & $0.119 * * *$ \\
\hline & {$[6.36]$} & {$[16.98]$} \\
\hline Analyst fixed effects & No & Yes \\
\hline Firm fixed effects & No & Yes \\
\hline Year fixed effects & Yes & Yes \\
\hline After matching & No & Yes \\
\hline Adjusted $R^{2}$ & $14.37 \%$ & $16.73 \%$ \\
\hline$N$ & 408,040 & 75,442 \\
\hline
\end{tabular}

Notes: Column (1) estimates the effect of cash flow forecast availability on target price accuracy using OLS estimation. Column (2) estimates the effect of cash flow forecast availability on target price accuracy on the matched sample. We report $t$-values based on standard errors clustered by analyst and firm in brackets. *** indicates a significance level of 0.01 . The Appendix provides variable definitions.

This article is protected by copyright. All rights reserved. 
TABLE 7

Estimation of the effect of cash flow forecast accuracy on target price error

\begin{tabular}{|c|c|}
\hline & TPerr \\
\hline \multirow[t]{2}{*}{ CFFerr } & $0.791 * * *$ \\
\hline & {$[15.90]$} \\
\hline \multirow[t]{2}{*}{ Accrual } & $0.112 * * *$ \\
\hline & {$[5.97]$} \\
\hline \multirow[t]{2}{*}{ AltmanZ } & 0.001 \\
\hline & {$[0.80]$} \\
\hline \multirow[t]{2}{*}{ Capital } & $0.004 * *$ \\
\hline & {$[2.13]$} \\
\hline \multirow[t]{2}{*}{ MCap } & $-0.093 * * *$ \\
\hline & {$[-30.18]$} \\
\hline \multirow[t]{2}{*}{ EVol } & $0.009 * * *$ \\
\hline & {$[3.88]$} \\
\hline \multirow[t]{2}{*}{ Freq } & $0.006 * * *$ \\
\hline & {$[6.17]$} \\
\hline \multirow[t]{2}{*}{ Star } & $-0.027 * *$ \\
\hline & {$[-2.38]$} \\
\hline \multirow[t]{2}{*}{ InstOwn } & $-0.059 * * *$ \\
\hline & {$[-4.72]$} \\
\hline \multirow[t]{2}{*}{ nAnal } & $0.005 * * *$ \\
\hline & {$[10.52]$} \\
\hline \multirow[t]{2}{*}{ EPSerr } & $0.364 * * *$ \\
\hline & {$[16.64]$} \\
\hline \multirow[t]{2}{*}{ StrBuy } & $0.025 * * *$ \\
\hline & {$[3.56]$} \\
\hline \multirow[t]{2}{*}{ Buy } & 0.008 \\
\hline & [1.53] \\
\hline \multirow[t]{2}{*}{ Sell } & 0.007 \\
\hline & {$[0.28]$} \\
\hline \multirow[t]{2}{*}{ Lev } & $0.151 * * *$ \\
\hline & {$[8.91]$} \\
\hline Analyst fixed effects & Yes \\
\hline Firm fixed effects & Yes \\
\hline Year fixed effects & Yes \\
\hline Adjusted $R^{2}$ & $10.3 \%$ \\
\hline$N$ & 38,650 \\
\hline
\end{tabular}

This article is protected by copyright. All rights reserved. 
TABLE 8

Estimation of the effect of cash flow forecast availability on target price error based on the same analyst for different firms

\begin{tabular}{|c|c|}
\hline & TPerr \\
\hline \multirow[t]{2}{*}{$C F F$} & $-0.070 * * *$ \\
\hline & {$[-16.80]$} \\
\hline \multirow[t]{2}{*}{ Accrual } & $1.032 * * *$ \\
\hline & [22.09] \\
\hline \multirow[t]{2}{*}{ AltmanZ } & $0.032 * * *$ \\
\hline & {$[5.93]$} \\
\hline \multirow[t]{2}{*}{ Capital } & $0.577 * * *$ \\
\hline & [10.37] \\
\hline \multirow[t]{2}{*}{ MCap } & $-0.379 * * *$ \\
\hline & {$[-19.35]$} \\
\hline \multirow[t]{2}{*}{ EVol } & $-0.133 * * *$ \\
\hline & {$[-20.56]$} \\
\hline \multirow[t]{2}{*}{ Freq } & $-0.066 * * *$ \\
\hline & {$[-7.18]$} \\
\hline \multirow[t]{2}{*}{ Star } & $0.136 * * *$ \\
\hline & {$[10.53]$} \\
\hline \multirow[t]{2}{*}{ InstOwn } & $-0.619 * * *$ \\
\hline & {$[-14.81]$} \\
\hline \multirow[t]{2}{*}{ nAnal } & $-0.023 * * *$ \\
\hline & {$[-4.83]$} \\
\hline \multirow[t]{2}{*}{ EPSerr } & $-0.201 * * *$ \\
\hline & {$[-10.55]$} \\
\hline \multirow[t]{2}{*}{ StrBuy } & $0.047 * * *$ \\
\hline & {$[5.06]$} \\
\hline \multirow[t]{2}{*}{ Buy } & $0.038 * * *$ \\
\hline & {$[3.23]$} \\
\hline \multirow[t]{2}{*}{ Sell } & $0.011 * * *$ \\
\hline & [17.49] \\
\hline \multirow[t]{2}{*}{ Lev } & $-0.764 * * *$ \\
\hline & {$[-6.43]$} \\
\hline Year fixed effects & Yes \\
\hline Adjusted $R^{2}$ & $39.6 \%$ \\
\hline$N$ & 6,756 \\
\hline
\end{tabular}

Notes: The table reports the results of estimating equation (2) separately for each analyst, where each analyst issues a target price and both cash flow and earnings forecasts for some firms, but only a target price and an earnings forecast for other firms, for a total of 6,756 regressions. We report the mean coefficients across 6,756 regressions and corresponding $t$-values; *** indicates a significance level of 0.01 . We also report the average adjusted $R^{2}$. The Appendix provides variable definitions.

This article is protected by copyright. All rights reserved. 
TABLE 9

The effect of cash flow forecast accuracy on target price error for more challenging-to-value firms compared with non-challenging-to-value firms

\begin{tabular}{|c|c|c|}
\hline & $\begin{array}{l}\text { TPerr } \\
\text { (1) }\end{array}$ & $\begin{array}{c}\text { TPerr } \\
\text { (2) }\end{array}$ \\
\hline$C F F$ & $\begin{array}{c}-0.038 * * * \\
{[-8.10]}\end{array}$ & \\
\hline Challenging & $\begin{array}{c}0.005 * * * \\
{[2.64]}\end{array}$ & $\begin{array}{c}-0.023 * * * \\
{[-3.34]}\end{array}$ \\
\hline$C F F \times$ Challenging & $\begin{array}{c}-0.020 * * * \\
{[-3.68]}\end{array}$ & \\
\hline CFFerr & & $\begin{array}{c}0.353 * * * \\
{[4.95]}\end{array}$ \\
\hline CFFerr $\times$ Challenging & & $\begin{array}{c}0.763 * * * \\
{[8.60]}\end{array}$ \\
\hline Accrual & $\begin{array}{l}0.069 * * * \\
{[10.64]}\end{array}$ & $\begin{array}{c}0.085 * * * \\
{[4.06]}\end{array}$ \\
\hline AltmanZ & $\begin{array}{l}0.006 * * * \\
{[31.95]}\end{array}$ & $\begin{array}{c}0.003 * * * \\
{[2.74]}\end{array}$ \\
\hline Capital & $\begin{array}{c}-0.027 * * * \\
{[-9.11]}\end{array}$ & $\begin{array}{c}-0.036 * * \\
{[-2.19]}\end{array}$ \\
\hline MCap & $\begin{array}{c}-0.115^{* * *} \\
{[-117.31]}\end{array}$ & $\begin{array}{l}-0.097 * * * \\
{[-26.87]}\end{array}$ \\
\hline EVol & $\begin{array}{l}0.026 * * * \\
{[35.29]}\end{array}$ & $\begin{array}{c}0.007 * * * \\
{[3.04]}\end{array}$ \\
\hline Freq & $\begin{array}{l}0.005^{* * * *} \\
{[12.16]}\end{array}$ & $\begin{array}{r}0.002 \\
{[1.18]}\end{array}$ \\
\hline Star & $\begin{array}{c}0.012 * * * \\
{[3.43]}\end{array}$ & $\begin{array}{r}-0.012 \\
{[-0.96]}\end{array}$ \\
\hline InstOwn & $\begin{array}{l}-0.153 * * * \\
{[-35.76]}\end{array}$ & $\begin{array}{c}-0.087 * * * \\
{[-4.99]}\end{array}$ \\
\hline nAnal & $\begin{array}{l}0.005^{* * *} \\
{[28.97]}\end{array}$ & $\begin{array}{c}0.004 * * * \\
{[5.46]}\end{array}$ \\
\hline EPSerr & $\begin{array}{c}0.671 * * * \\
{[111.09]}\end{array}$ & $\begin{array}{l}0.342 * * * \\
{[15.55]}\end{array}$ \\
\hline StrBuy & $\begin{array}{l}0.076^{* * * *} \\
{[29.20]}\end{array}$ & $\begin{array}{c}0.051 * * * \\
{[4.42]}\end{array}$ \\
\hline Buy & $\begin{array}{l}0.034 * * * \\
{[17.10]}\end{array}$ & $\begin{array}{c}0.018 * * * \\
{[2.84]}\end{array}$ \\
\hline Sell & $\begin{array}{l}0.101 * * * \\
{[13.56]}\end{array}$ & $\begin{array}{l}0.062 * \\
{[1.93]}\end{array}$ \\
\hline Lev & $\begin{array}{l}0.124 * * * \\
{[23.20]}\end{array}$ & $\begin{array}{c}0.194 * * * \\
{[8.18]}\end{array}$ \\
\hline
\end{tabular}

This article is protected by copyright. All rights reserved. 
Analyst fixed effects

Firm fixed effects

Year fixed effects

After matching

Adjusted $R^{2}$
Yes

Yes

Yes

Yes

$11.6 \%$

75,442
Yes

Yes

Yes

No

$10.5 \%$

38,650

Notes: The table estimates the effect of cash flow forecast error on target price accuracy, where the dummy variable Challenging defines a firm that is more challenging to value based on whether it makes a loss in the year before the analyst forecast announcement, it has a limited number of industry peers in the sample, it is small, or it has high risk. The observations in column (1) are from the matched sample; the observations in column (2) are from the CFF sample. We report $t$-values based on standard errors clustered by analyst and firm in brackets. ***, **, and * indicate a significance level of $0.01,0.05$, and 0.10 , respectively. The Appendix provides variable definitions.

TABLE 10

Additional controls and analysis

\begin{tabular}{|c|c|c|c|c|c|c|c|c|c|c|c|}
\hline \multirow{3}{*}{$\begin{array}{l}\text { Depen } \\
\text { dent } \\
\text { variabl } \\
\text { e } \\
\text { TPerr }\end{array}$} & \multirow{2}{*}{\multicolumn{2}{|c|}{$\begin{array}{l}\text { Up vs. down } \\
\text { markets }\end{array}$}} & \multirow{2}{*}{$\begin{array}{l}\text { Foreca } \\
\text { st } \\
\text { horizo } \\
\text { n }\end{array}$} & \multirow{2}{*}{\multicolumn{2}{|c|}{ ixcluding energy }} & \multicolumn{3}{|c|}{ Subperiods } & \multicolumn{3}{|c|}{ Subperiods } \\
\hline & & & & & & $\begin{array}{l}2000- \\
2003\end{array}$ & $\begin{array}{l}2004- \\
2006\end{array}$ & $\begin{array}{l}2007- \\
2010\end{array}$ & $\begin{array}{l}2000- \\
2003\end{array}$ & $\begin{array}{l}2004- \\
2006\end{array}$ & $\begin{array}{l}2007- \\
2010\end{array}$ \\
\hline & (1) & (2) & (3) & (4) & (5) & (6) & (7) & (8) & (9) & (10) & (11) \\
\hline & -0.043 & & & -0.047 & & -0.032 & -0.011 & -0.074 & & & \\
\hline$C F F$ & $* * *$ & & & $* * *$ & & $* *$ & $* *$ & $* * *$ & & & \\
\hline & {$[-9.82]$} & & & {$[-8.98]$} & & $\begin{array}{l}{[-2.22} \\
]\end{array}$ & $\begin{array}{l}{[-2.28} \\
]\end{array}$ & $\begin{array}{l}{[-7.04} \\
]\end{array}$ & & & \\
\hline CFFer & & $0.764 * *$ & $0.769^{* *}$ & & $0.813^{*}$ & & & & & & $0.879 *$ \\
\hline$r$ & & $*$ & $*$ & & $\begin{array}{l}* * \\
{[13.18}\end{array}$ & & & & $0.304 *$ & $1.010 * * *$ & $* *$ \\
\hline Contro & & [15.41] & [15.41] & & & & & & [1.70] & [8.51] & [15.11] \\
\hline $\begin{array}{l}1 \\
\text { covari } \\
\text { ates }\end{array}$ & Yes & Yes & Yes & Yes & Yes & Yes & Yes & Yes & Yes & Yes & Yes \\
\hline $\begin{array}{l}\text { Additi } \\
\text { onal } \\
\text { control } \\
\text { variabl } \\
\text { es }\end{array}$ & $U p$ & $U p$ & $\begin{array}{l}\text { Horizon } \\
\text { CF, } \\
\text { Horizon } \\
T P\end{array}$ & & & & & & & & \\
\hline $\begin{array}{l}\text { Sampl } \\
\mathrm{e}\end{array}$ & $\begin{array}{c}\text { Full } \\
\text { sample }\end{array}$ & $\begin{array}{c}\text { CF } \\
\text { sampl } \\
\mathrm{e}\end{array}$ & $\begin{array}{c}\mathrm{CF} \\
\text { sample }\end{array}$ & $\begin{array}{c}\text { No } \\
\text { energy } \\
\text { sector }\end{array}$ & $\begin{array}{c}\text { No } \\
\text { energy } \\
\text { sector }\end{array}$ & $\begin{array}{c}\text { Years } \\
2000- \\
2003\end{array}$ & $\begin{array}{c}\text { Years } \\
2004- \\
2006\end{array}$ & $\begin{array}{c}\text { Years } \\
2007- \\
2010\end{array}$ & $\begin{array}{c}\text { Years } \\
2000- \\
2003\end{array}$ & $\begin{array}{c}\text { Years } \\
2004- \\
2006\end{array}$ & $\begin{array}{c}\text { Years } \\
2007- \\
2010\end{array}$ \\
\hline $\begin{array}{l}\text { After } \\
\text { matchi } \\
\text { ng }\end{array}$ & Yes & No & No & Yes & Yes & Yes & Yes & Yes & No & No & No \\
\hline $\begin{array}{l}\text { Analys } \\
\text { t fixed }\end{array}$ & Yes & Yes & Yes & Yes & Yes & Yes & Yes & Yes & Yes & Yes & Yes \\
\hline
\end{tabular}

This article is protected by copyright. All rights reserved. 
effects

\begin{tabular}{|c|c|c|c|c|c|c|c|c|c|c|c|}
\hline $\begin{array}{l}\text { Firm } \\
\text { fixed } \\
\text { effects }\end{array}$ & Yes & Yes & Yes & Yes & Yes & Yes & Yes & Yes & Yes & Yes & Yes \\
\hline $\begin{array}{l}\text { Year } \\
\text { fixed } \\
\text { effects }\end{array}$ & Yes & Yes & Yes & Yes & Yes & Yes & Yes & Yes & Yes & Yes & Yes \\
\hline $\begin{array}{l}\text { Adjust } \\
\text { ed } R^{2}\end{array}$ & $\begin{array}{r}12.10 \\
\%\end{array}$ & $\begin{array}{r}11.00 \\
\% \\
38,65\end{array}$ & $10.40 \%$ & $\begin{array}{l}11.30 \% \\
336,54\end{array}$ & $7.00 \%$ & $11.9 \%$ & $6.29 \%$ & $\begin{array}{r}11.62 \\
\%\end{array}$ & $5.42 \%$ & $8.98 \%$ & $\begin{array}{r}15.83 \\
\%\end{array}$ \\
\hline$N$ & 75,442 & 0 & 38,650 & 1 & 24,998 & 8,282 & 20,646 & 46,537 & 3,340 & 9,181 & 26,129 \\
\hline
\end{tabular}

Notes: The table presents the results of additional analysis. Column (1) [(2)] estimates the effect of cash flow forecast availability [cash flow forecast error] on target price accuracy controlling for the effect of up vs. down markets. Column (3) estimates the effect of cash flow forecast error on target price accuracy, controlling for target price and cash flow forecast horizons. Column (4) [(5)] estimates the effect of cash flow forecast availability [cash flow forecast error] on target price accuracy excluding energy companies. Columns (6)-(8) [(9)-(11)] estimate the effect of cash flow forecast availability [cash flow forecast error] on target price accuracy for the subperiods 2000-2003, 2004-2006, and 2007-2010. Estimations involving $C F F$ are after matching and include the propensity score as a covariate. We report $t$-values based on standard errors clustered by analyst and firm in brackets. ***,**, and * indicate a significance level of $0.01,0.05$, and 0.10 , respectively. The Appendix provides variable definitions.

\section{Appendix Variable definitions}

\begin{tabular}{|c|c|c|}
\hline Variable & Variable name & Definition \\
\hline Accrual & $\begin{array}{l}\text { Magnitude of } \\
\text { accruals }\end{array}$ & $\begin{array}{l}\text { Absolute value of net income before extraordinary items minus } \\
\text { operating cash flows divided by total assets }\end{array}$ \\
\hline AltmanZ & Altman's Z-score & $\begin{array}{l}Z=1.2 \text { (Net working capital / Total assets })+1.4 \text { (Retained earnings } / \\
\text { Total assets })+3.3 \text { (Earnings before interest and taxes } / \text { Total assets })+ \\
0.6 \text { (Market value of equity / Book value of liabilities })+1.0(\text { Sales } / \\
\text { Total assets) }\end{array}$ \\
\hline Buy & $\begin{array}{l}\text { Buy } \\
\text { recommendation } \\
\text { dummy }\end{array}$ & $\begin{array}{l}\text { Equals one when the analyst stock recommendation is buy, and zero } \\
\text { otherwise }\end{array}$ \\
\hline Capital & Capital intensity & Gross property, plant, and equipment divided by revenue \\
\hline$C F F$ & $\begin{array}{l}\text { Cash flow } \\
\text { forecast dummy }\end{array}$ & $\begin{array}{l}\text { Equals one if the observation includes a cash flow forecast, and zero } \\
\text { otherwise }\end{array}$ \\
\hline CFFerr & $\begin{array}{l}\text { Cash flow } \\
\text { forecast error }\end{array}$ & $\begin{array}{l}\text { Absolute value of the difference between the analyst cash flow } \\
\text { forecast minus the actual realized cash flow per share at the end of } \\
\text { the forecast period, divided by the price at the time of forecast }\end{array}$ \\
\hline Challenging & $\begin{array}{l}\text { Challenging firm } \\
\text { dummy }\end{array}$ & $\begin{array}{l}\text { Equals one if the firm is more challenging to value based on } \\
\text { company size, risk, profitability, or number of industry peers, and } \\
\text { zero otherwise. Challenging-to-value firms are small (market } \\
\text { capitalization in the lowest quartile of our sample by year), high risk } \\
\text { (earnings volatility in the highest quartile of our sample by year), } \\
\text { loss-making (negative reported earnings), or have five or fewer } \\
\text { industry peers according to the Global Industry Classification } \\
\text { Standard }\end{array}$ \\
\hline EPSerr & $\begin{array}{l}\text { Earnings forecast } \\
\text { error }\end{array}$ & $\begin{array}{l}\text { Absolute value of the difference between the analyst earnings per } \\
\text { share forecast minus the actual realized earnings per share at the end } \\
\text { of the forecast period, divided by the sharemarket price at the time of }\end{array}$ \\
\hline
\end{tabular}

This article is protected by copyright. All rights reserved. 


\section{forecast}

\begin{tabular}{|c|c|c|}
\hline EVol & $\begin{array}{l}\text { Earnings } \\
\text { volatility }\end{array}$ & $\begin{array}{l}\text { Natural logarithm of the standard deviation of earnings over the past } \\
\text { four quarters, where earnings is total earnings before extraordinary } \\
\text { items }\end{array}$ \\
\hline Freq & $\begin{array}{l}\text { Forecast } \\
\text { frequency }\end{array}$ & $\begin{array}{l}\text { Number of target price revisions issued by a given analyst for the } \\
\text { company in the year }\end{array}$ \\
\hline Hold & $\begin{array}{l}\text { Hold } \\
\text { recommendation } \\
\text { dummy }\end{array}$ & $\begin{array}{l}\text { Equals one when the analyst stock recommendation is hold, and zero } \\
\text { otherwise }\end{array}$ \\
\hline InstOwn & $\begin{array}{l}\text { Institutional } \\
\text { ownership }\end{array}$ & $\begin{array}{l}\text { Total number of shares held by institutional investors divided by the } \\
\text { total number of shares outstanding }\end{array}$ \\
\hline Lev & Leverage & Company's debt-to-assets ratio for the year \\
\hline MCap & $\begin{array}{l}\text { Market } \\
\text { capitalization }\end{array}$ & Natural logarithm of the company's equity market value \\
\hline nAnal & $\begin{array}{l}\text { Number of } \\
\text { analysts } \\
\text { following }\end{array}$ & $\mathrm{I} / \mathrm{B} / \mathrm{E} / \mathrm{S}$ number of analysts following the company in the year \\
\hline Sell & $\begin{array}{l}\text { Sell } \\
\text { recommendation } \\
\text { dummy }\end{array}$ & $\begin{array}{l}\text { Equals one when the analyst stock recommendation is sell, and zero } \\
\text { otherwise }\end{array}$ \\
\hline Star & $\begin{array}{l}\text { Star analyst } \\
\text { dummy }\end{array}$ & $\begin{array}{l}\text { Equals one if the analyst is an Institutional Investor Star analyst in } \\
\text { the year before the release of the current analyst forecast, and zero } \\
\text { otherwise }\end{array}$ \\
\hline StrBuy & $\begin{array}{l}\text { Strong buy } \\
\text { recommendation } \\
\text { dummy }\end{array}$ & $\begin{array}{l}\text { Equals one if the analyst stock recommendation is strong buy, and } \\
\text { zero otherwise }\end{array}$ \\
\hline TPerr & $\begin{array}{l}\text { Target price } \\
\text { forecast error }\end{array}$ & $\begin{array}{l}\text { Absolute value of the difference between the target price and the } \\
\text { market price at the end of the forecast horizon divided by the current } \\
\text { market price }\end{array}$ \\
\hline
\end{tabular}

This article is protected by copyright. All rights reserved. 